\title{
The social value creation of MNEs - a literature review across multiple academic fields
}

Social value creation of MNEs
Noemi Sinkovics

Alliance Manchester Business School, The University of Manchester, Manchester, UK and The University of Auckland, Auckland, New Zealand, and

Jason Archie-acheampong

Alliance Manchester Business School, The University of Manchester, Manchester, UK

\begin{abstract}
Purpose - This study aims to investigate how different academic fields within and outside of international business (IB) engage with the topics of social value creation in the context of multinational enterprises (MNEs). The aim is to take stock of the main themes and offer suggestions for future research avenues.

Design/methodology/approach - The paper undertakes a scoping review. The authors use the Web of Science database to identify relevant articles. The database search yielded 466 articles. The NVivo software was used to code and identify key thematic areas.

Findings - The matrix analysis performed in NVivo yielded 15 main thematic areas spanning 37 research fields. However, further analysis revealed that 89 per cent of the articles originated from 13 fields. Furthermore, while IB journals represent the second-largest field home to publications related to the social value creation of MNEs, they only account for 12 per cent of the sample.
\end{abstract}

Originality/value - The paper responds to prior calls to reduce disciplinary silos through the performing of a thematic analysis across a multitude of research fields.

Keywords CSR, Multinational enterprise, Social value, MNE, Scoping review

Paper type Literature review

\section{Introduction}

The purpose of this paper is to investigate how different academic fields engage with the topic of social value creation in the context of multinational enterprises (MNEs). While recent studies attempt to provide a more clear-cut conceptualisation of social value (Sinkovics et al., 2015; Sinkovics et al., 2014), for the purposes of this review we will adopt a very general definition to capture a broader range of scholarly engagement with the topic (Sinkovics et al., 2019). More specifically, we regard any positive societal or environmental outcome that arises from the activities of MNEs as social value. Although there are a number of practical and theoretical reasons why such an investigation would be useful, the main motivation behind this particular study stems from the urgent need to take stock and take action.

(C) Noemi Sinkovics and Jason Archie-acheampong. Published by Emerald Publishing Limited. This article is published under the Creative Commons Attribution (CC BY 4.0) licence. Anyone may reproduce, distribute, translate and create derivative works of this article (for both commercial and non-commercial purposes), subject to full attribution to the original publication and authors. The full terms of this licence may be seen at http://creativecommons.org/licences/by/4.0/legalcode
Received 30 June 2017 Revised 21 December 2018 3 May 2019 Accepted 6 May 2019 


\section{CPOIB}

16,1

The socio-ecological challenges facing society are producing immediate impacts that can already be felt today. They are no longer possibilities of a distant future. A fairly recent approach to assessing global sustainability identifies nine planetary boundaries that define a safe operating space for humanity (Rockstrom et al., 2009a; Rockstrom et al., 2009b). Research results demonstrate that several of these safe boundaries have already been exceeded, including biodiversity loss and climate change (Steffen $e$ t al., 2015). This has serious implications for the future of humanity and, as firms cannot be separated from human beings, for future business models as well as global value chains (Elkington and Braun, 2013; Linnenluecke et al, 2016). The youth climate strikes in over a 100 countries have demonstrated that the new generation not only feels this urgency but is also prepared to take action (Taylor et al.,2019). As a consequence, the self-interest of MNEs is bound to move closer to the needs of society. The question is simply, can the required transition take place proactively, under optimal terms for humanity, or will it be reactive and effectuated in haste?

George et al. (2016) emphasise that global problems cannot be solved in isolation. They highlight the need for coordination and collaborative efforts to address these grand challenges. Grand challenges can be defined as the formulation and operationalisation of global problems. While there are many attempts to formulate global challenges, the 17 Sustainable Development Goals (SDGs) and the (currently) 232 indicators can be seen as the most universal and widespread (George et al., 2016). As the wealth of some of the world's largest MNEs exceeds that of emerging and smaller nations (Inman, 2016), they are well positioned to contribute meaningfully to these collaborative efforts. However, such contributions are not merely a question of financial means, but most importantly a question of capability (Wettstein, 2012). There is ample evidence that, when they do not develop capabilities to identify and address internal and external constraints on their contributions to grand challenges, MNE initiatives often fail or produce unintended negative consequences (Sinkovics et al., 2016; Sinkovics et al., 2015; Sinkovics et al., 2014).

When it comes to the research side of grand challenges, the most critical question is no longer the recognition that these problems exist, but how to facilitate the transformative change necessary to hedge against their negative impact (Fazey et al., 2018). Buckley, Doh, and Benischke (2017) suggest that international business (IB) as a discipline is uniquely positioned to make a contribution. An important prerequisite is a rapid upscaling of research in this area (Fazey et al, 2018). A recent literature review on social responsibility dimensions (both positive and negative) in $14 \mathrm{IB}$ journals, uncovered that, while the number of publications related to responsibility has increased steadily since 2006, research related to grand challenges is still relatively underrepresented in these journals (Sinkovics et al, 2019). However, this does not mean that IB scholars are not working on the topic. It merely means that they may have published their research in other journals whose remit is closer to the social responsibility agenda.

It is to this end that in this paper we do not limit our search to specific journals. The aim is to investigate how different academic fields engage with the topics of social value creation in the context of MNEs. We deem such an effort necessary in order for research on grand challenges to be fast-tracked. This is because these topics are multifaceted and different fields may have different approaches and underlying assumptions. As Sinkovics et al. (2019) point out, literature reviews can provide a good starting point for scholars new to an area of research, or inspiration for new research ideas for scholars already familiar with the topic. The rest of the paper is structured as follows. First, we provide a brief conceptual background and an overview of the methods employed in this research. Subsequently, we present the findings, organised according to the field from which they emerged. We designate the succeeding section to a discussion of potential future research avenues. The conclusion section highlights what we deem as the main take-away message and discusses the limitations of the study. 


\section{Conceptual background and review methods}

Early efforts to conceptualise the interface of business and society define social responsibility as the obligations businessmen have towards meeting the 'objectives and values' of our society (Bowen, 1953). Both market and non-market strategies characterise the behaviour of MNEs (Devinney, 2011), as they increasingly participate in cross-border foreign direct investment (FDI) inflows and disaggregated global production. To this end, within the business and management literature(s), various concepts are used to account for the heterogeneous nature of non-market strategies; examples include business ethics (Chakrabarty and Bass, 2015; Hartlieb and Jones, 2009), corporate governance (Bondy et al., 2008; Cohen et al., 2002), sustainability (Brandi, 2017; Ciliberti et al., 2009), philanthropy (Brammer et al., 2009; Mithani, 2017) and business and human rights (Wettstein, 2010; Windsor, 2006). Not only do studies in this area consider the relationships MNEs have with global workers, the environment and the communities in which their operations occur, but they also situate the MNE as a political actor (Scherer et al., 2006) creating both economic and social value.

However, studies addressing social value creation in MNEs are not limited to business and management. They can be situated across various bodies of literature, such as IB, business ethics, development studies, economic geography, environmental studies, human rights law, to name just a few. The present literature review accounts for this variation by not limiting the search to specific journals. We used the Web of Science database to perform the search. In light of the heterogeneous nature of the definition of social value creation, our search string included a wide range of key words: TS[1] = ("multinational corporation" OR "multinational enterprise" OR "transnational corporation" OR "transnational enterprise" OR "multinational compan*” OR "transnational compan*" OR "MNE" OR "TNC" OR "MNC" OR “TNE” OR "global value chain" OR "global production network" OR "GVC" OR "GPN" OR "lead firm" OR "global supply chain") AND TS = ("social value" OR "social performance" OR "corporate social responsibility” OR "CSR" OR “ethics” OR "ethical” OR "human rights" OR "philanthropy" OR "altruism" OR "social innovation" OR "inclusive growth" OR "doing good" OR "stakeholder" OR "social responsibility" OR "social issue" OR "societal impact" OR "poverty reduction" OR "environmental sustainability" OR "triple bottom line" OR "millennium development goal” OR "MDG” OR "sustainable development goal” OR "SDG” OR “sustainable development” OR "economic development” OR "poverty reduction" OR "social upgrading” OR “corporate citizenship").

To make sure that we did not miss any studies in ethics journals that focussed on MNEs, we performed the following search using ISSN numbers[2]: (IS=(0007-6503 OR 0045-3609 OR 0167-4544 OR 0925-6733 OR 0962-8770 OR 1052-150X OR 1511-6670 OR 1535-3958 OR 1746-5680 OR 1747-1117 OR 1817-7417 OR 2041-2568 OR 2196-7083 OR 2210-6723) AND $\mathrm{TS}=$ ("multinational corporation" OR "multinational enterprise" OR "transnational corporation" OR "transnational enterprise" OR "multinational compan*” OR "transnational compan*” OR "MNE" OR "TNC" OR "MNC" OR "TNE" OR "global value chain" OR "global production network" OR "GVC" OR "GPN" OR "lead firm" OR "global supply chain"). This search yielded 30 new papers. The search was conducted in November 2017, which represents the cut-off point for inclusion. The two search strings identified 565 papers in total. We excluded book chapters and other non-relevant papers. We used the following inclusion criteria for the final selection: the paper should explicitly mention MNEs (domestic large corporations were excluded); the paper should explicitly mention the direct social/environmental impact of MNEs (e.g. impact on workers, impact on environment, impact on communities, impact on government policies, etc.). After cleaning the sample, 466 papers were left.

We subsequently imported the articles in PDF format, as well as the corresponding bibliographic information (author, title, journal name, year of publication, Web of Science

Social value creation of MNEs 


\section{CPOIB}

16,1

\section{0}

identification number, etc.), into the NVivo software. The bibliographic information was linked to each PDF through the source specification sheet. To be able to conduct a crossdisciplinary analysis, we added an additional attribute to the source specification sheet, which we named "research field". To define the research fields, we adapted Harzing's (2017) journal classifications. Table I provides an overview of the disciplinary areas and the number of articles identified in each area. We subsequently read through the 466 articles and coded them. Table II lists the main themes and the number of articles in each theme. Table III provides more detailed information about the themes and sub-themes that emerged through the coding process performed using NVivo.

\section{Findings}

The analysis yielded 15 overarching themes, with disparate studies being classified as "other" (Tables II and III). The main themes were spread across 37 fields (Table I). However,

Research discipline

Agriculture

Area Studies

Biology

Business Ethics

Business History

Biotechnology and Applied Microbiology

Chemistry

Communication

Criminology and Penology

Economics

Ecology

Engineering

Environmental Sciences

Entrepreneurship

Environmental Studies

Ethics

Accounting and Finance

General Management and Strategy

Geography

Health Policy and Services

Hospitality, Leisure, Sport and Tourism

Innovation

International Business

International Relations

Law

Management Information Systems, Knowledge Management

Marketing

Medicine

Multidisciplinary Sciences

Operations Research, Management Science, Production and Operations Management

Organisation Behaviour/Studies, Human Resource Management and Industrial Relations

Planning and Development

Table I.

Number of articles per research discipline

Public, Environmental and Occupational Health

Public Sector Management

Public Sector Management and Education

Social Sciences

Sociology

No. of articles

1
5
1
144
1
1
1
3
1
15
2
3
1
3
32
1
15
47
23
3
2
3
58
9
15
1
8
3
1
12
20
17
4
3
2
1
4


Theme

Bottom of the pyramid

Conflict-peace

Corporate governance

Corporate irresponsibility

Ethics

Headquarters-subsidiaries

Human resource management-employment

Institutional setting impact

International law-regulation

Legitimacy-liability of foreignness

Other

Responsibility in GVCs/supply chains

MNEs and development

Stakeholder management

Sustainability

Theoretical integration efforts
Social value creation of MNEs

a matrix query across themes and research fields determined that 89 per cent of the results (415 articles) were contributed by 13 fields. Not surprisingly, the field with the largest number of articles in our sample is the field of business ethics (144 articles), followed by IB and general management and strategy, with 58 and 47 papers respectively. In the categories of environmental studies, geography, organisation studies/behaviour/HRM/industrial relations, and planning and development there were 32, 23, 20, and 17 studies respectively. The fields of law, economics, and accounting and finance (A\&F) each yielded 15 studies. In the fields of operations research/management science/production and operations management, international relations, and marketing our search identified 12,9 and 8 papers, respectively.

However, it is important to remember that our specific search strategy limited the results to the context of MNEs, thus excluding research on large domestic corporations and on small and medium-sized enterprises (SMEs). Furthermore, studies that did not explicitly mention the term MNE (or related search terms) were not captured by the search. These results nevertheless suggest that, while journals in the field of business ethics are in the lead in social-value-related research, we are seeing an encouraging increase in this area within IB journals, as well as in general management and strategy journals. A temporal analysis revealed that, from 2008 onward, there has been a steady increase in publications on socialvalue-related topics in each of the aforementioned 13 fields.

Table IV presents the distribution of the 16 main themes that emerged from the analysis, across the 13 fields. The theme that receives most of the attention within this sub-sample is related to dimensions of responsibility and social value creation in global value chains (GVCs) or supply chains. However, a more in-depth analysis shows that only 4 of the 88 papers on this topic are published in IB journals. Other themes that are comparatively under-represented in IB journals are related to stakeholder management, MNEs and development, international law, sustainability, ethics, and corporate irresponsibility (Table IV). The remainder of this section looks into each of the 13 fields in more detail.

\subsection{International business}

Research within IB most notably explores the transfer of corporate social responsibility (CSR) practices from headquarters to subsidiaries, the role of institutional influences on CSR uptake and outcomes, CSR as a form of legitimacy and way to overcome the liability of 


\section{CPOIB \\ 16,1}

\begin{tabular}{|c|c|}
\hline Research theme & Sub-theme \\
\hline $\begin{array}{l}\text { Bottom of the } \\
\text { pyramid }\end{array}$ & $\begin{array}{l}\text { Business model design } \\
\text { Ethical dimensions } \\
\text { Capabilities } \\
\text { Strategic dimensions } \\
\text { The role of innovation } \\
\text { Sustainable supply chain management }\end{array}$ \\
\hline Conflict-peace & $\begin{array}{l}\text { Facilitating peace and conflict resolution } \\
\text { Contributing to conflict } \\
\text { Investment in conflict regions }\end{array}$ \\
\hline $\begin{array}{l}\text { Corporate } \\
\text { governance }\end{array}$ & $\begin{array}{l}\text { Codes of conduct } \\
\text { Reporting } \\
\text { Regulatory frameworks and institutional dynamics } \\
\text { Taxation }\end{array}$ \\
\hline $\begin{array}{l}\text { Corporate } \\
\text { irresponsibility }\end{array}$ & $\begin{array}{l}\text { Corruption (firm and institutional level) } \\
\text { The dark side of CSR } \\
\text { Unfair treatment of employees } \\
\text { Falsification in reporting } \\
\text { Consumer retaliation }\end{array}$ \\
\hline Ethics & $\begin{array}{l}\text { Leadership } \\
\text { Country-level variance } \\
\text { Employee ethics } \\
\text { Company culture } \\
\text { Outcomes of (un)ethical behaviour }\end{array}$ \\
\hline
\end{tabular}

Social value creation in subsidiary firms

Human resource management (HRM)

Antecedents and motivations Implementation

Example reference

Arnold and Valentin (2013), Gold et al. (2013), Hall et al. (2014), London and Hart (2004), Perrot (2017), Schrader et al. (2012), Sinkovics et al. (2014) Driffield et al. (2013), Getz and Oetzel (2009), Idemudia (2014b), Kolk and Lenfant (2010), Srikantia (2016) Bondy et al. (2008), Chiu and Wang (2015), Lauwo et al. (2016), Venter et al. (2017)

Buldybayeva (2014), Chai et al. (2016), Giraudo (2005), Halter et al. (2009), Lindgreen (2004), Williams and Zinkin (2008)

Bell et al. (2012), CalderonCuadrado et al. (2009), Chang et al. (2017), Kelly (2004), Li and Murphy (2012), Myer et al. (2016), Nygaard et al. (2017), Verhezen, 2010) Gruber and Schlegelmilch (2015), Jamali (2010a), Momin and Parker (2013), Surroca et al. (2013))

Kim and Scullion (2011), Lorenzo et al. (2010), Shen (2011), Tsai and Shih (2013))

Institutional dynamics and social value creation

Ethical dimensions

CSR and HRM

Workplace conditions

The role of trade unions

Institutional distance

Operating in institutional voids

The role and impact of formal and informal institutions

International law

International Framework Agreements (IFAs) and regulation

Consumer regulation

Influence of international law

Impact of national regulations on firm behaviour

Legitimacy-

liability of foreignness (LOF)

Other Social value creation as a form of legitimacy Overcoming the LOF

SMEs vs MNEs

Business education

Corporate political activity

Health-related impacts of MNEs

Country-specific CSR development

Table III.

Organisational learning and social value creation

Alas and Edwards (2011), Busse et al. (2016), Dam and Scholtens (2012), El Ghoul et al. (2017), Husted and Allen (2006), Lattemann et al. (2009), Marano and Kostova (2016) Compa (2002), Egels-Zanden (2009), LeBaron and Ruhmkorf (2017), Lustig (2014), Palmer (2001), Tan (2009) Campbell et al. (2012), Crilly et al., 2016; Gifford and Kestler (2008), Mithani (2017) (Brammer et al. (2006), Frynas (2010), Ha-Brookshire et al. (2017), Jamali et al. (2009), Ma et al. (2016), Monfort and Villagra (2016), Morsing and Perrini (2009), Pedersen and (continued) 


\begin{tabular}{|c|c|c|}
\hline Research theme & Sub-theme & Example reference \\
\hline & $\begin{array}{l}\text { Impact of internationalisation and diversification } \\
\text { social value creation } \\
\text { Firm-level outcomes of social value creation }\end{array}$ & $\begin{array}{l}\text { Neergaard (2009), Salcito et al. } \\
\text { (2014), Sampson and Ellis } \\
\text { (2015), Smith (2010), Yang } \\
\text { et al. (2012) }\end{array}$ \\
\hline \multirow{6}{*}{$\begin{array}{l}\text { Responsibility in } \\
\text { GVCs }\end{array}$} & Governance & Bair and Palpacuer (2015), \\
\hline & Labour and employment & Barrientos et al. (2016), \\
\hline & Developmental outcomes of GVCs & Bostrom (2015), Franz and \\
\hline & Power in GVCs & Hassler (2010), Giri and Singh \\
\hline & Implementation of social value creation in GVCs & (2016), Henderson et al. (2002), \\
\hline & Upgrading & $\begin{array}{l}\text { Jorgensen and Milanez (2017), } \\
\text { Lee and Gereffi (2015), Pipkin } \\
\text { (2011), Smith and Barrientos } \\
\text { (2005), Touboulic et al. (2014) }\end{array}$ \\
\hline \multirow{4}{*}{$\begin{array}{l}\text { MNEs and } \\
\text { development }\end{array}$} & Positive and negative impacts & Crisan-Mitra et al. (2016), \\
\hline & Approaches & Frynas (2005), Garcia- \\
\hline & Challenges & Rodriguez et al. (2013), Gupta \\
\hline & Contextual & $\begin{array}{l}\text { (2017), Hartman et al. (2011), } \\
\text { Idemudia (2014a), Lyons et al. } \\
\text { (2016), Ramamurti (2004) }\end{array}$ \\
\hline \multirow{4}{*}{$\begin{array}{l}\text { Stakeholder } \\
\text { management }\end{array}$} & Governmental impact & Beckman et al. (2009), Burchell \\
\hline & Business-NGO relationships & and Cook (2013), Ibanez (2015), \\
\hline & Public-community influence & Imbun (2007), Ritvala et al. \\
\hline & Stakeholder management & $\begin{array}{l}\text { (2014), Wang and Sengupta } \\
\text { (2016) }\end{array}$ \\
\hline \multirow[t]{2}{*}{ Sustainability } & Environmental sustainability & Acquaye et al. (2015), \\
\hline & Capability building in sustainability & $\begin{array}{l}\text { Aguilera-Caracuel et al. (2012), } \\
\text { Golini et al. (2014), Riikkinen } \\
\text { et al. (2017) }\end{array}$ \\
\hline \multirow{19}{*}{$\begin{array}{l}\text { Theoretical } \\
\text { integration efforts }\end{array}$} & Conceptual contributions & Arnold, 2010; Devinney, 2011; \\
\hline & The concept of power in CSR & Doh and Lucea, 2013; Drebes, \\
\hline & CSR and global strategy & 2016; Giuliani and Macchi, \\
\hline & Ethical obligations across countries & 2014; Hemphill and Lillevik, \\
\hline & Social value creation as social constraint alleviation & 2011; Oetzel and Doh, 2009; \\
\hline & $\begin{array}{l}\text { Rights and responsibilities of corporations towards } \\
\text { the poor }\end{array}$ & Sinkovics et al., 2015 \\
\hline & Libertarian views of the corporation & \\
\hline & The end of virtuous capitalism & \\
\hline & Human rights discourses & \\
\hline & Review studies & \\
\hline & GVC research & \\
\hline & Ethics and IB & \\
\hline & Economic and human rights impact on developing & \\
\hline & countries & \\
\hline & FDI in China, CSR as an emerging theme & \\
\hline & Non-market research and global strategy & \\
\hline & MNEs and development & \\
\hline & The triple bottom line and cyber security & \\
\hline & $\begin{array}{l}\text { Sustainable and responsible supply chain } \\
\text { governance }\end{array}$ & \\
\hline
\end{tabular}

MNEs and

Approaches

Challenges

Contextual

Governmental impact

Business-NGO relationships

Public-community influence

Environmental sustainability

Capability building in sustainability

Conceptual contributions

CSR and global strategy

Ethical obligations across countries

Libertarian views of the corporation

The end of virtuous capitalism

Ethics and IB

Economic and human rights impact on developing countries

MNEs and development

Sustainable and responsible supply chain governance
Table III. 
CPOIB

16,1

14

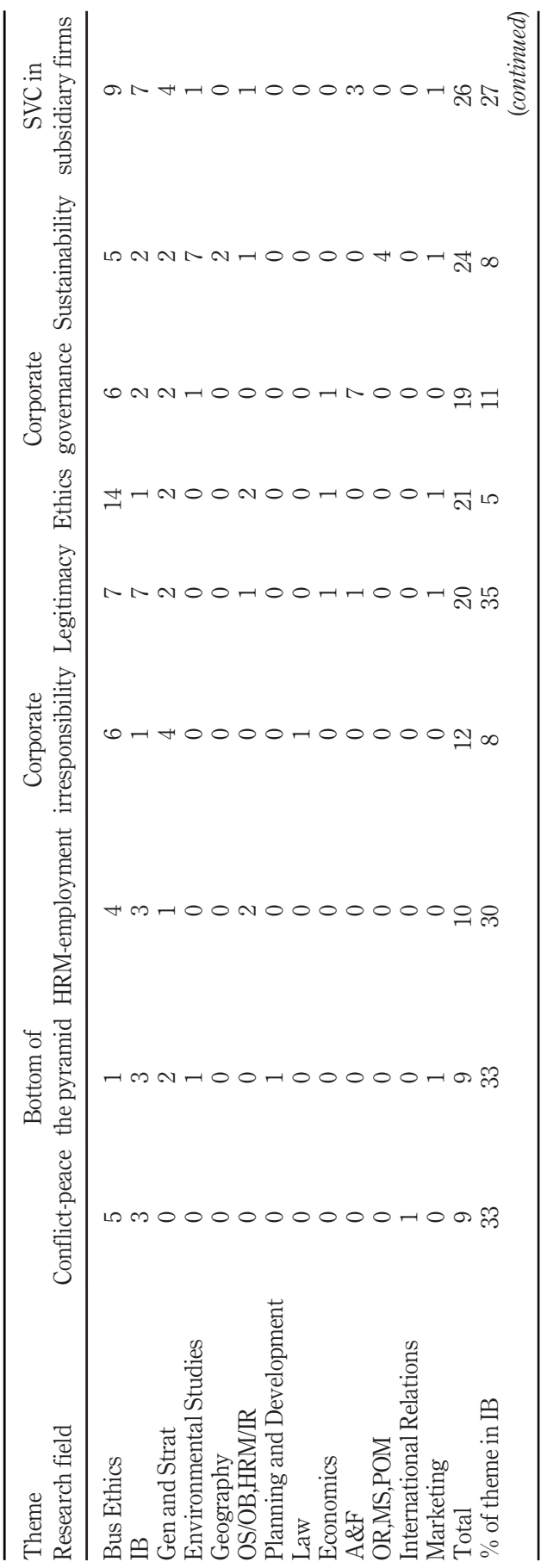

Table IV.

Breakdown of articles on main themes according to main research field 


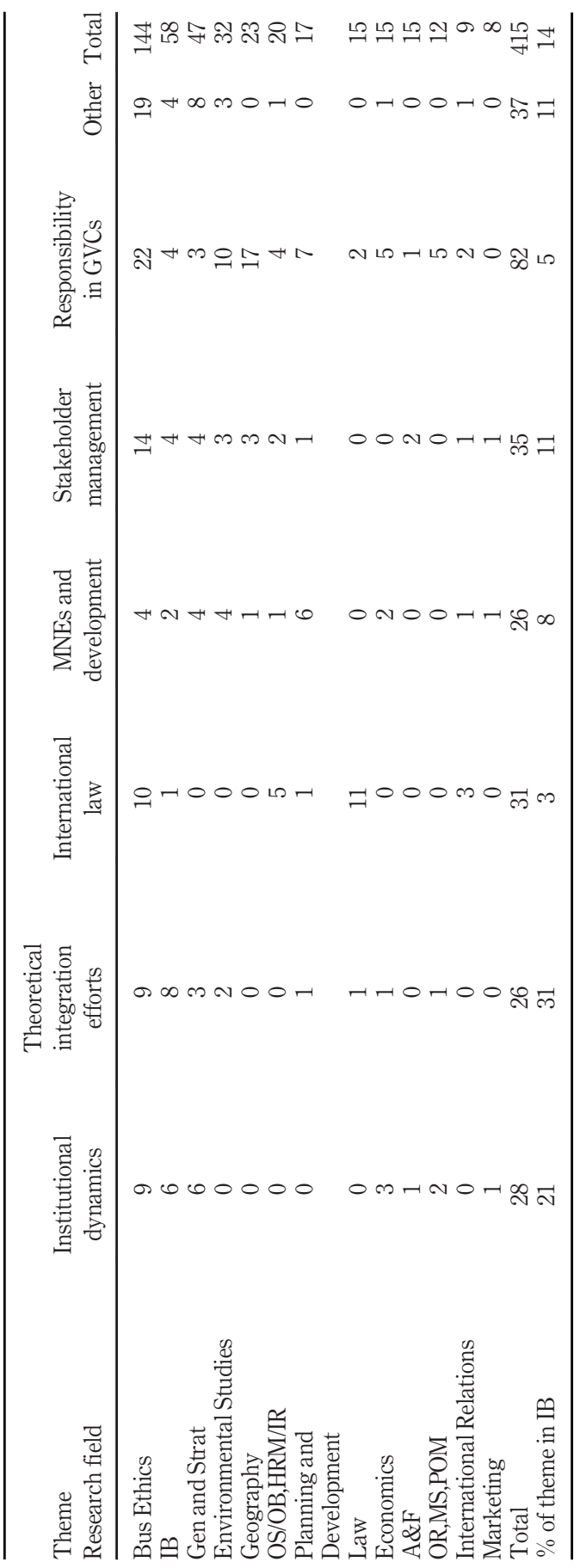

Social value creation of MNEs 
CPOIB 16,1

foreignness, conflict and corporate irresponsibility, and the relationship between CSR and human resource management (HRM).

In terms of the transfer of social value creation practices from MNE headquarters to subsidiary firms, research explores the determinants of CSR adoption in subsidiaries (Park and Choi, 2015). Evidence suggests that, when there is higher regulatory distance between the subsidiary and its headquarters, the subsidiary will disclose more on its remuneration policies to gain legitimacy (Riaz et al., 2015). Furthermore, research shows that peer conformity to CSR shapes CSR behaviour in subsidiaries (Durand and Jacqueminet, 2015), and when implementing CSR in developing markets, local CSR engagement is more effective in creating positive development outcomes than global standards (Morgenroth and Luiz, 2017). Furthermore, studies exploring environmental management practices in subsidiaries (Tatoglu et al., 2014) find that, when subsidiaries have a shared level of absorptive capacity, it facilitates consensual knowledge on environmental issues (Pinkse et al., 2010).

When considering the role of the MNE in its institutional environment, institutional pressures, rather than stakeholders and the strategic consideration of social issues, are found to guide CSR decision making (Husted and Allen, 2006). Findings also indicate that, when the quality of institutions is high, the impact of FDI on local firms' CSR uptake diminishes (Nyuur et al., 2016), and when MNEs and their subsidiaries experience high country distance, there is a greater propensity for weakening consumer loyalty and trust, which affects corporate reputation (Swoboda et al., 2017). In the context of emerging market multinationals (EMNEs), evidence suggests that high institutional distance has a positive impact on their equity participation (Gaffney et al., 2016).

MNEs are found to acquire legitimacy and a social license to operate when they are able to create local sustainable benefits for the communities in which they operate (Gifford and Kestler, 2008), offer socially valuable goods (Darendeli and Hill, 2016), engage with the local community (Reimann et al., 2012), and participate in CSR-based activities (Husted et al., 2016; Selmier et al., 2015). Other studies suggest that firms can overcome their liability of foreignness in new markets by engaging in philanthropic activities (Mithani, 2017). However, Sinkovics et al. (2014) point out that, with some notable exceptions, MNEs tend not to be well equipped to understand local constraints. This is in line with London and Hart's (2004) emphasis on the importance of MNEs developing capabilities that facilitate their social embeddedness. Similarly, Sinkovics et al. (2015) propose that, to create genuine social value, a business needs to be able to alleviate a social constraint or, if the process of alleviation is lengthy (some issues take generations to resolve), address a significant symptom of the constraint. For example, Pinkse and Kolk (2012) examine the impact of climate change on MNEs as they seek to overcome the institutional failures associated with the phenomenon in the global context.

The few studies in our sample that consider corporate irresponsibility and the relationship between MNEs and conflict contribute the following insights. Driffield $e$ al. (2013) find that companies with less concern about CSR are more likely to invest in conflict regions. When MNEs face local stakeholder pressure they are more likely to respond directly to conflict, whereas when they experience international stakeholder pressure, they are more likely to respond indirectly to conflict (Oetzel and Getz, 2012). From a context perspective, evidence suggests that, when there is a high level of perceived corruption, the philanthropic activity of an MNE decreases (Luo, 2006). Finally, Srikantia (2016) relates the violent destruction of sustainable communities to the process of globalisation.

Contributions to HRM explore CSR and its relationship with global talent management. Results suggest that MNEs that practice CSR will experience higher levels of employee engagement and retention (Kim and Scullion, 2011). Furthermore, studies exploring the relationship between sustainability and HRM report on how corporate sustainability 
objectives can be embedded within an organisation and transferred between two different foreign-located firms (Wehling et al., 2009).

\subsection{Business ethics}

The field of business ethics places notable attention on a wide range of areas, including the implementation of social value across GVCs, development impacts of MNEs, the social value outcomes of business-NGO (non-governmental organisations) relationships and institutional dynamics, conflict resolution, and corruption.

The UN global compact has been instrumental in establishing guidelines for MNEs on human rights, labour, corruption, and the environment (Williams, 2004). This has subsequently facilitated international decision making on human rights (Jackson, 2000) and the use of ethical standards in the institutionalisation of ethics across global supply chains (Krueger, 2008). In the area of governance, codes of conduct and certifications are implemented as MNE-led management processes aimed at coordinating suppliers (Lim and Phillips, 2008; Mamic, 2005; McClintock, 1999; Yu, 2008) and regulating sustainability and ethical trade in GVCs (Reed, 2009; Wahl and Bull, 2014). However, early critical perspectives highlight the limitations of codes of conduct in terms of embedding social activities in supplier firms (McClintock, 1999). This has led to calls for the need to go beyond superficial CSR codes (Lim and Phillips, 2008). Findings also suggest that management systems do not strongly predict CSR performance (Mijatovic and Stokic, 2010). Similarly, the existence and implementation of formal codes of ethics is not found to be a sufficient condition for the preservation of corporate reputations. Only in combination with good and honest relationships with suppliers do they seem to have the desired effect (Bendixen and Abratt, 2007). A balanced combination of monitoring and trust in buyer-supplier relationships also seems to foster upstream responsibility (Bostrom, 2015). The identification of locally appropriate responses in host markets (Lund-Thomsen and Nadvi, 2010), the creation of shared responsibility (Hemphill and Kelley, 2016), and the adoption of voluntary governance mechanisms geared towards shared value (Soundararajan and Brown, 2016) are also identified as necessary conditions for positive outcomes. However, to identify locally appropriate responses, MNEs need to understand the prevailing complexities in a given emerging or developing market (cf. Wang, 2005).

The field of business ethics contributes the most papers on MNEs' interaction with NGOs, civil society groups (Burchell and Cook, 2013; Collins, 2009), and the local communities in which they operate (Imbun, 2007). Investigations include the role of civil society in driving the CSR agenda in firms (Mzembe and Meaton, 2014) and as watchdogs of MNEs (Tuokuu and Amponsah-Tawiah, 2016). Evidence points to cooperative approaches being more effective than confrontational approaches in ensuring the responsibility of firms (Egels-Zanden and Hyllman, 2006). Furthermore, cooperative methods for addressing social and environmental challenges are found to be more achievable when the two parties share capabilities or are willing to mitigate each other's weaknesses (de Lange et al., 2016). Despite this, NGOs can suffer from 'NGO capture', limiting their ability to ensure MNE compliance to codes of conduct through a need to appease MNEs (Sethi and Rovenpor, 2016). Nevertheless, public-private regimes that are characterised by non-hierarchical compliance mechanisms are regarded as more effective in keeping MNEs accountable for upholding human rights (Kobrin, 2009). Furthermore, partnerships with NGOs can help firms gain legitimacy (Skippari and Pajunen, 2010) and minimise instability (Lucea, 2010) in host countries.

Another stream of research explores the impact of institutional characteristics on the implementation of ethical behaviour (Alas and Wei, 2008; Bondy et al., 2012; Jamali, 2010b; Miska et al., 2016; Pedersen and Gwozdz, 2014; Samy et al., 2015; Zhao et al., 2014).
Social value creation of MNEs 


\section{CPOIB}

16,1

Investigations include how institutional dynamics shape work-related values (Alas and Wei, 2008), the role of the state in the global integration of CSR (Miska et al., 2016) and the impact of institutional voids on corporate social irresponsibility (Zhao et al., 2014). Tan (2009) argues that, in order for the CSR performance of an MNE to improve, the legal framework and ethical culture of its institutional environment needs to be strong. Scherer et al. (2006) discuss the ability of MNEs to create a framework of rules and regulations for the global economy. However, as MNEs operate across porous borders, it is proposed that greater restrictions be placed on them to ensure they conform with international standards on human rights (Palmer, 2001).

Another strand of research in this field addresses social value from an employee perspective. While earlier studies argue that neither managers nor shareholders should exercise moral judgment on the grounds that they are not free agents (Dobson, 1992), managers who lead the way on ethics can enhance employees' commitment to ethical behaviour (Nygaard et al., 2017), as corporate values impact on the personal behaviour and values of employees (Cambra-Fierro et al., 2008). Ethics hotlines are novel examples of organisational mechanisms whereby employees can report corporate wrongdoings (Calderon-Cuadrado et al., 2009). Evidence also indicates that firms are able to overcome moral silence within their workforces by moving beyond compliance and embracing organisational cultures based on integrity (Verhezen, 2010).

When looking at the relationship between MNEs and socio-economic development, CSR is argued to have a positive impact by bringing employment to developing countries (Sargent and Matthews, 1999), helping to solve community problems (Forcadell and Aracil, 2017), and improving the administrative and legislative functions of the market environment (GarciaRodriguez et al., 2013). Lozano and Boni (2002) emphasise the role of MNEs in the economic social and cultural development of countries, through the nature of their activities. They furthermore investigate the recommendations of three supranational organisations, namely, the International Labour Organization and the Organisation for Economic Co-operation and Development, and conclude that there is a need for application and control mechanisms to maximise their impact.

An emerging theme is the contribution of MNEs to conflict or peace. MNEs respond through "direct-indirect" or "unilateral-collaborative" interventions to minimise the investment risk created through conflicts in host markets (Getz and Oetzel, 2009). Studies highlight the role of standards, albeit a limited one, in facilitating conflict resolution (Koerber, 2009), and draw attention to the role of external factors such as trade unions and NGO partnerships in innovatively tackling community-level conflict (Kolk and Lenfant, 2013). However, as demonstrated by Shell's presence in the Niger delta, although MNEs may seek to facilitate peace, profit-making objectives can contribute to the deterioration of stakeholder relationships and therefore undermine conflict resolution (Idemudia, 2014b).

Furthermore, studies on corporate irresponsibility primarily focus on corruption. To minimise corruption practices, firms adopt anti-corruption codes (Lindgreen, 2004) and tools to promote transparency (Halter et al., 2009). From an institutional perspective, the level of corruption at the national level impacts on a firm's investment commitment (Luo, 2011). Additionally, there seem to be cultural variations in the way consumers respond to business irresponsibility (Williams and Zinkin, 2008). In the area of tax avoidance, findings show that MNE subsidiaries known for their CSR activities pay more taxes than subsidiaries less known for their CSR activities (Muller and Kolk, 2015).

\subsection{General management and strategy}

General management and strategy comprise the third-largest number of papers in our sample. Topics range from the transfer of CSR practices to subsidiaries, to the institutional impact on social value creation, to stakeholder management, to corruption. 
In terms of the strategic transfer of CSR to emerging markets, non-business actors influence the CSR strategies of subsidiaries (Ljung and Pahlberg, 2015). Yin and Jamali (2016) explore the nature and process of MNE subsidiaries' strategic CSR practices in China. They develop an analytical framework encompassing strategic CSR orientations, the strategic CSR process, the different economic and social value outcomes and the relevant firm-context contingencies.

In terms of the drivers of social value creation in MNE subsidiaries, findings suggest that increasing stakeholder pressure from the country of origin may lead to socially irresponsible practices in subsidiary firms (Surroca et al., 2013). Furthermore, regarding the challenges of implementing CSR strategies in subsidiaries, MNEs encounter difficulties in defining corporate ethics and facilitating organisational learning aimed towards responsible business behaviour (Cruz and Pedrozo, 2009).

Strategies for creating social value differ across institutional contexts (Filatotchev and Nakajima, 2014), prompting calls for a non-standardised approach to implementing CSR (Kim et al., 2013). MNEs face varying institutional forces, with the overall impact dependent on their relative importance to the firm (Marano and Kostova, 2016). Applying Hofstede's cultural dimensions framework, Pedrini et al. (2016) find that institutional contexts characterised by power distance, individualist/collectivist, and uncertainty avoidance negatively impact efforts towards CSR and environmental practices. Research also explores the implementation of CSR in contexts characterised by limited statehood and weak formal institutions. Firms are able to manage the associated risks of operating in these environments by interacting with public governance structures (Hanekom and Luiz, 2017), and forming relationships with non-state actors (Azizi and Jamali, 2016).

Although investing in cooperative stakeholder relationships can be costly for firms (Garcia-Castro and Francoeur, 2016), it can enhance a firm's brand equity and financial performance (Wang and Sengupta, 2016) and research finds that, when partnered with NGOs, MNEs are able to facilitate social and environmental outcomes (Perez-Aleman and Sandilands, 2008). Joutsenvirta and Vaara (2009) investigate the subtle meaning-making processes of social actors surrounding socially contested corporate action. Based on their findings, they propose that, in CSR debates, corporate representatives tend to apply legalistic frames, highlight their expert knowledge and attempt to disassociate from political disputes.

In this field, studies investigating firm-level corruption find that high levels of formal and informal corruption may lead to high levels of corporate social irresponsibility (Keig et al., 2015). Conversely, a strong CSR performance can reduce the risk of corporate corruption (Lopatta et al., 2017). Firm-level corruption can furthermore lead to 'legitimacy shocks' and therefore negatively affect the firm (Schembera and Scherer, 2017). However, in emerging markets consumers are less likely to punish corrupt firms as they tend to be characterised by price sensitivity and place less importance on the ethical behaviour of a firm (Iriyama et al., 2016).

\subsection{Marketing}

Marketing studies predominately address the relationship between consumers and social value creation in MNEs. Findings suggest that MNEs target social development initiatives in specific markets to enhance specific resource capabilities and therefore their overall competitiveness (Gupta, 2017). Sustainable export marketing strategies balance environmental and commercialisation objectives, and are impacted by various macro and micro environmental factors in a firm's home and export markets (Zeriti et al., 2014). In the African context, Gruber and Schlegelmilch (2015) find evidence of the adaptation of CSR
Social value creation of MNEs 
CPOIB 16,1

strategies by MNE regional headquarters to fit local settings. When located in emerging markets, firms can enhance their market position by using CSR to gain trust and legitimacy (Hadjikhani et al., 2016). Furthermore, despite weak formal institutions, MNCs use CSR programmes to enhance their brand value (Khan et al., 2015; Tarnovskaya and Biedenbach, 2016). Other studies detail the effects of company transgressions on the reasoning processes of consumers (Chang et al., 2017) and argue that, when located in bottom of the pyramid $(\mathrm{BoP})$ markets, despite their unethical practices, MNEs are still able to retain consumer loyalty (Gupta and Srivastav, 2016).

\subsection{Organisational studies/behaviour, human resource management and industrial relations}

Studies in this area are particularly concerned with social value creation with respect to employees and organisational behaviour. From an organisational culture perspective, studies explore the role of religious beliefs within organisations (Bell et al., 2012) and how having an ethical orientation improves firm profitability (Myer et al., 2016). From a GVC perspective, studies primarily focus on conceptualising employee relations in GVCs (Donaghey et al., 2014; Lakhani et al., 2013), and examine the negative impact financial crises have had in terms of increasing work intensification and job insecurity in global commodity chains (Taylor et al., 2014). Furthermore, researchers explore the role of international framework agreements (IFAs) in regulating labour representation (Dehnen, 2013; Helfen et al., 2016; Sobczak, 2007) and the importance of international law in advancing global rights (Compa, 2002), as voluntary regimes have shown to be inadequate at ensuring MNEs are not complicit in human rights violations (Simons, 2004). Although an underexplored area, there are studies that integrate the notion of CSR into international HRM (Shen, 2011) and, from a green HRM perspective, address how environmental sustainability can be achieved through the engagement of employees in related practices (Haddock-Millar et al., 2016). The role of external global production network (GPN) actors in facilitating certain outcomes for workers is also examined. More specifically, Plank and Staritz (2016) look into the impact of state policies on the social up/downgrading of workers in supplier firms. Chowdhury (2017) investigates the complicity of 'elite' NGOs in violating workers' rights when partnered with MNEs, and Tsai and Shih (2013) focus on the role of labour unions in negotiating responsible outcomes for workers during organisational downsizing.

\subsection{Operations research, management science, production and operations management}

Studies in this area particularly focus on sustainability issues within supply chains. Firms create social value through environmental supply chain management (Wichmann et al., 2016) and responsible supplier selection (Griffis et al., 2014). Green supply chains (Mollenkopf et al., 2010) and environmental labelling through Fairtrade (Acquaye et al., 2015) exemplify how firms can achieve environmental sustainability. Golini et al. (2014) argue that operational competencies that go beyond production activities are key antecedents for environmental and social sustainability. Findings also highlight the influence of institutional pressures in driving social sustainability initiatives (Kauppi and Hannibal, 2017) and that of institutional distance on supply chain sustainability risks (Busse et al., 2016). Furthermore, research finds that CSR can help mitigate supply chain risks (Cruz, 2013a), whilst power is used to manage sustainability risks in supply chains between buyers and suppliers (Touboulic et al., 2014). 


\subsection{Accounting and finance}

Studies published in journals associated with this field focus on corporate governance tools related to social value creation. Findings suggest that MNEs often use CSR reporting to legitimise the CSR activities of subsidiaries (Belal and Owen, 2015; Momin and Parker, 2013). Accounting protocols have also been found to serve as a legitimation tool for employee downsizing (Makela and Nasi, 2010). Other findings suggest that dividend policies in subsidiaries are not necessarily driven by CSR requirements, but rather the remittance demands of the parent company (Kim and Jeon, 2015). Stakeholders provide resistance to the hegemony of MNEs (Pupovac and Moerman, 2017), with the media being key in holding MNEs to account (Deegan and Islam, 2014; Islam and Deegan, 2010). Additionally, firms' corporate responsibility communication seems to be driven by the institutional environments in which they operate (Lattemann et al., 2009). Therefore, for CSR reporting to be effective, there need to be strong regulatory measures in place (Lauwo et al, 2016). Beyond the aforementioned areas, more recent studies discuss the relationship between tax avoidance and CSR reporting, transparency in tax disclosures (Venter et al., 2017; Ylonen and Laine, 2015), and the voluntary disclosure of MNEs' investments (Cannizzaro and Weiner, 2015).

\subsection{Environmental studies}

Not surprisingly, studies on MNEs in this field tend to focus on sustainability issues and the environmental impacts of firms. When implementing corporate sustainability objectives, subsidiaries' levels of self-determination seem to play an important role in their governance choices. Recognising these differences in corporate motivations and needs is important, because they shape the extent of corporations' contributions to local communities and environments (Shah and Arjoon, 2015). When investigating global supply chains, Cruz (2013b) finds that socially responsible chains are more efficient than their less responsible counterparts. In a similar vein, Cruz (2013a) proposes that CSR can potentially be used as a risk mitigation strategy. However, despite the positive impacts environmental upgrading can have on individual firms, these benefits easily diminish when foreign buyers push standards down the chain and there is no financial or technical assistance (Achabou et al., 2017). Helin and Babri (2015) highlight the issue of the negotiability of ethics and sustainability when efficiency and contractual agreements are the primary shapers of the audit process. Findings like these make a striking call for the co-creation of standards and certifications between firms and NGOs to ensure positive sustainability outcomes (Vellema and van Wijk, 2015).

There is a notable strand within this literature attempting the interdisciplinary integration of concepts that might foster transformation such as organisational change, organisational strategy, and sustainability (Sroufe, 2017). For example, Schrader et al. (2012) emphasise that BoP solutions need to equally consider aspects of internal organisation, supply chain management, and sustainability outcomes. Other topics include the examination of how different corporate carbon management accounting approaches might converge to create an overarching carbon accounting system (Gibassier and Schaltegger, 2015), the role of corporations in and their impact on fresh water usage (Lambooy, 2011), the use of polyethylene terephthalate (PET) bottles to reduce the environmental impact of plastic in global supply chains (Accorsi et al., 2015), tackling e-waste to enable global environmental justice (Pickren, 2014), instruments for creating green supply chains (Rueda, Garrett, and Lambin, 2017), and the use of sustainability assessments to determine whether sourcing locally would be more sustainable than sourcing globally (Brunori et al., 2016). Further topics include the unintended negative consequences of new technologies such as genetically modified crops (Tait and Chataway, 2007) and the downstream exporting of hazardous products to developing countries (Jorgensen and Milanez, 2017). 


\section{CPOIB}

16,1

\subsection{Geography, planning and development and area studies}

Given that most studies associated with these three research fields adopt a GVC/GPN lens, we collapsed them into one overarching category. The GVC/GPN frameworks provide a holistic approach for analysing the social and economic impacts of geographically dispersed economic activities (Bridge, 2008; Bridge and Bradshaw, 2017; Horner, 2016; Mahutga, 2012; Stringer et al., 2014; Werner, 2016). Studies honing in on the role of the state look at a number of issues. For example, while Horner (2017) explores the role of the state in facilitating firm participation in GVCs, Alford (2016) describes the nature of trans-scalar governance deficits for precarious workers in the context of South African fruit sector. Under certain conditions, governments may be able to foster positive MNE development impacts by imposing trade barriers that encourage better cooperation between MNEs and local farmers (Ibanez, 2015).

Research on monitoring and certifications cover a range of topics. For example, Seidman (2005) compares different models of transnational monitoring. McQuilken (2016) documents the failure of ethical certifications to empower artisanal and small-scale workers in the goldmining sector in sub-Saharan Africa. Smith and Barrientos (2005) propose that convergence between the ethical and fair-trade movements will depend on corporate culture, values, and strategies. Focussing on private standards and codes of conduct, Raj-Reichert (2013) looks at the self-regulatory nature of these governance programmes, while Pangsapa and Smith (2008) investigate environmental and labour standards, as well as CSR initiatives against the complexities of globalisation. Furthermore, evidence suggests that improving the capabilities of developing-country producers can foster compliance with sustainability requirements (Tolentino-Zondervan et al., 2016).

Studies interested in social upgrading investigate gendered patterns of consumption and production (Barrientos, 2014), the gendered and racial nature of disarticulation in economic and social upgrading (Christian, 2016a), and the creation of environmentally certified niches as a counter-measure to the negative impact of GVC/GPN participation (Klooster and Mercado-Celis, 2016). As an outcome of their investigation in the Bangladeshi garment sector, Alam and Natsuda (2016) observe that, although the industry has achieved functional upgrading, it still faces challenges with respect to social upgrading. Pipkin (2011) proposes that the nature of labour relations and local history play an important role in upgrading outcomes. Yeung (2009) demonstrates that regional development needs to be viewed against the context of the changing dynamics of GPNs.

Further topics include explorations on e-waste recycling in enabling environmental protection (Tong and Wang, 2004) and the unintended negative consequences of certain technologies on climate change adaptation (Carey et al., 2012). Sesan et al. (2013) warn that profit-driven business models at the $\mathrm{BoP}$ are not sufficient to meaningfully serve these markets. MNEs can contribute to local communities by providing electricity access (D'Amelio et al., 2016; Wilde-Ramsing, 2017), supporting biodiversity projects (Bek et al., 2013), funding sport and gender development (Hayhurst, 2011), and partnering in quadsector development projects to tackle corruption (Gonzalez, 2016).

Other studies explore the notion of power in global organic value chains (Franz and Hassler, 2010) and examine the role of ethical campaigning in counteracting MNE power and authority (Hughes et al., 2008).

\subsection{Economics}

Studies in this category find that institutional conditions, such as an independent judiciary system and a good level of national security, have a positive impact on triple-bottom-line reporting (Urban and Hwindingwi, 2016). Furthermore, evidence suggests attitudes toward society, organisations and work are influenced individual's cultural background as well as 
the institutional context (Alas and Edwards, 2011). Findings also imply that MNEs with a high level of social responsibility tend to avoid locating in countries with weak environmental regulation (Dam and Scholtens, 2008), and polluting firms tend to be located in countries with weak regulation (Dam and Scholtens, 2012). For private governance incentives on workers' rights to be effective, the political motivations of the host governments must also align with protecting workers' rights (Mosley, 2017).

Although globalisation has contributed to employment creation and greater labour mobility, it has also created negative outcomes (Maertens et al., 2011). The GPN framework offers an approach for analysing asymmetries in economic and social development (Henderson et al., 2002). Meanwhile, some critical voices suggest that the GVC approach may be used to extend neoliberal agendas in developing countries (Fernandez, 2015) and that firm upgrading does not necessarily lead to improved labour conditions (Knorringa and Pegler, 2006).

\subsection{International relations}

Studies in this area consider the relationship between firms and political systems (Butler, 2000; Halvorsen and Jakobsen, 2013). Findings highlight the role of state regulation and international law in ensuring human rights protection (Karp, 2009; Scheinin, 2012) and regulating CSR behaviour (LeBaron and Ruhmkorf, 2017). Research also finds that social compliance programmes aimed at improving workers' rights have been shown to be ineffective in repressive countries with state-controlled unions (Anner, 2017).

\subsection{Law}

Studies originating from this field focus on the role international law and transnational governance have on maintaining human rights and the responsibilities of MNEs (Lustig, 2014; Murphy, 2005; Neglia, 2016; Regan, 2016; Seck, 2016). The dispersal of global production activities makes it difficult to prevent human rights abuses committed abroad (Parella, 2014). Other studies investigate the effectiveness of instruments such as the Alien Tort Statute (Bu, 2015; Wu, 2001). Martin (2013) finds that there is increasing pressure on firm directors to incorporate human rights issues into their corporate governance frameworks. Beyond international regulation, national governments are integral to the governance of human rights, with existing studies examining the impact of domestic legislation on global supply chain transparency (e.g. UK Modern Slavery Act) (Sarfaty, 2015) and the shared responsibility both states and MNEs must take in addressing human rights (Karavias, 2015; Neglia, 2016).

\subsection{Other fields}

The remaining 51 studies in our literature database were distributed across 23 research fields. Given the low number of studies in each field, we summarise the findings under this sub-section. Studies in the fields of medicine and health policy specifically focus on healthrelated impacts/interventions of MNEs. Within public and occupational health, studies investigate the health impact of MNEs (Singh et al., 2010), highlighting the need for regulatory frameworks and guidelines that will limit negative effects (Anaf et al., 2017; Baum et al., 2016; Yang et al., 2012). Medicine-based studies also highlight MNEs' potential role in controlling disease and infection (Salcito et al., 2014), and tackling food allergens in food supply chains (Cantani, 2009), whilst also exploring the ethicality of drug-marketing efforts (Hartog, 1993). Additionally, studies within health policy and services investigate the positive and negative human rights impacts of MNEs (Salcito et al., 2015) and their role in contributing to deficient health development (Tausch and Heshmati, 2012). 
CPOIB 16,1

Ecological studies examine the failings of GVC sustainability criteria to address the needs of smallholder farmers (Noor et al., 2017) and the negative by-products of biotechnology production and their impact on the environment (Mannion, 1995). However, biotechnology can also contribute towards addressing the problem of malnutrition (Monastra and Rossi, 2003). In chemistry, transformative business models are shown to incorporate green chemistry and nanotechnology so as to foster sustainability outcomes (Fiksel, 2001). Finally, a single study categorised under environmental science examines developments on the increased use of environmental reporting by resource-based south eastern MNEs (Dura et al.. 2017).

Within innovation research, studies explore the effect of FDI, through innovation, on the gross domestic product of a nation (Binh and Linh, 2013), and the use of innovation pathways to facilitate economic and social development in BoP markets (Hall et al., 2014). Engineering research offers perspectives on CSR through explorations of the 'dark side' of CSR and the negative impacts of CSR activities in the oil and gas industry (Buldybayeva, 2014), as well as the adverse effects MNE trade and governance have had in creating water insecurities in local communities (Vos and Hinojosa, 2016).

Criminological and sociological research investigate corporate irresponsibility by exploring evidence from international financial institutions (Rothe, 2010). In sociology-based studies, authors consider socio-economic development in light of "the post-Washington consensus" (Werner et al., 2014), discuss the limitations of CSR in addressing poverty (Hasan, 2013), and the contribution of FDI to economic inequality (Tausch and Heshmati, 2012).

Scholars within public sector management and education focus on the role of MNEs in driving governmental health policy (Powell and Gard, 2015), and highlight the positive contributions MNEs can make towards female participation in higher education (Clark, 1992). Finally, Lober (1997) examines business-environmentalist group collaborations aimed at addressing environmental issues regarding paper production by participating in governmental policy.

Within hospitality leisure, sport and tourism, two studies explore the uneven social and upgrading outcomes experienced by workers and communities in tourism-based GPNs (Christian, 2016b), and the positive contribution GPN actors - rather than international hotel firms - have on regional economic development (Niewiadomski, 2015). Communication studies examine corporate reporting in response to consumer criticism (Rim and Song, 2017), the impact of social media in empowering the public to speak out against MNE responsibilities (Yin et al., 2015), and the use of CSR to manage local cultures and deal with tensions (Mak et al., 2015). Similarly, within the field of management information systems and knowledge management, authors look at CSR from a marketing and consumer engagement perspective, by exploring its influence on brand management (Monfort and Villagra, 2016).

In the field of multidisciplinary sciences, a single study investigates the role of private food standards in creating a barrier for smallholder producers and hindering poverty alleviation (Lee et al., 2012). Similarly, within the field of biotechnology and applied microbiology, the role of foreign trade in economic development is examined (Luo, 2017). In agriculture, Amekawa (2009) examines the rise of public good agricultural practice standards and their potential to facilitate better social, economic, and environmental outcomes through the inclusion of 'global south' producers. Historical studies in entrepreneurship investigate the past employment practices of first-mover MNEs, describing the discriminatory treatment of host-country nationals (Chai et al., 2016). Within the field of ethics, research investigates the management of ethics in supply chains, and 
product design issues that present subsequent reputational risks (Gilbert and Wisner, 2010). Finally, in business history and social sciences, authors respectively explore what constitute the responsibilities of entrepreneurs (Sluyterman, 2012), and the impact of the state in light of the changing role of MNEs (Turner and Corbacho, 2000).

\section{Future research avenues}

This paper has set out to take stock of research on the social value creation of MNEs across different fields. Although scholarly efforts have made broad inroads into the area, there remains space for extension through the synergising of key thematic areas. This section outlines some of these areas.

\subsection{Alternative models of governance}

Across the different fields, compliance programmes for improving workers' rights have been shown to be ineffective (Anner, 2017; Lim and Phillips, 2008). However, there is evidence that codes are integral to tackling corruption (Lindgreen, 2004) and, although proposals have been made for more trust-based mechanisms to be used to govern social value creation in supply chains, it is not recommended that this be in place of formal monitoring structures (Bostrom, 2015). In light of the limitations associated with formal management codes and certifications in generating positive development outcomes, IB research will benefit from empirical investigations that go beyond formal buyer-led compliance programmes to further explore how MNEs engage through non-hierarchical governance structures (Kobrin, 2009) and alternative forms of governance that bring about positive outcomes for developing-country producers.

\subsection{Social value creation through business-NGO partnerships}

Further work is required to examine the conditions under which MNE-NGO collaborations are successful, including the capabilities required for such collaboration. In addition, future research may wish to investigate the extent to which NGOs can actually participate in the strategy creation and implementation processes of partner firms.

\subsection{The influence of host-market consumers on multinational enterprises' social value creation}

Stakeholder theory is often drawn on by scholars examining the factors that influence social value creation in MNEs. Such work accounts for the role of governments and NGOs, although a limited number of studies also discuss the impact of consumer pressure. Beyond IB, research investigates the regulatory role of consumers (Seidman, 2005), with evidence suggesting that emerging-market consumers place less emphasis on the ethical behaviour of firms as such consumers are characterised by price sensitivity (Iriyama et al., 2016). Furthermore, research demonstrates the vulnerability of consumers as, despite unethical practices, firms are able to retain consumer loyalty when they are located in BoP markets (Gupta and Srivastav, 2016). However, how consumer characteristics shape social value outcomes warrants further investigation. Comparative studies would provide a nuanced understanding on the localisation and standardisation of social value creation in response to consumer preferences, for firms operating across international markets.

\subsection{The role of the state in multinational enterprises' social value creation}

Although MNEs may respond to regulatory gaps in governance to a certain extent, state regulation and international law remains vital in ensuring human rights protection,
Social value creation of MNEs 
CPOIB 16,1

regulating CSR behaviour, and facilitating social upgrading (Karp, 2009; LeBaron and Ruhmkorf, 2017; Plank and Staritz, 2016; Scheinin, 2012). Future research may wish to engage more with the role the state plays in driving MNEs' social value creation.

\subsection{Capabilities for social value creation}

Research results indicate that, to achieve positive sustainability outcomes, firms must enhance their absorptive capacity (Pinkse et al., 2010; Riikkinen et al., 2017). Other studies emphasise the importance of recognising and alleviating the root causes of social and environmental problems (Sinkovics et al., 2015; Sinkovics et al., 2014). This suggests that firms that are able to recognise and alleviate such root causes possess a distinctive set of capabilities that allows them to do so. Future research may wish to explore the conditions under which such capabilities can be developed.

\subsection{Transferring social value through human resource management}

Socially responsible international HRM that seeks to enhance employee working conditions can be a source of legitimacy in firms (Shen, 2011), and support the management of global talent. Evidence suggests that MNEs that practise CSR will experience higher levels of employee engagement and retention, thus contributing to their competitiveness (Kim and Scullion, 2011). When adopting green HRM approaches, firms can achieve environmental sustainability by engaging employees in related practices (Haddock-Millar et al., 2016). Furthermore, studies exploring the relationship between sustainability and HRM examine how corporate sustainability objectives can be embedded within an organisation and transferred between two different foreign locations (Wehling et al., 2009). Future research in IB may wish to further explore the conditions that hinder or facilitate the transfer of social value creation practices across locations of production, and how social value creation can be better embedded organisationally.

\subsection{More emphasis on environmental sustainability}

Environmental studies have widely explored the various practices firms adopt to minimise environmental impacts. Despite this, research on how MNEs integrate both environmental and social sustainability objectives into their subsidiaries and suppliers remains relatively underexplored within IB. Greater integration efforts will foster a more systems-based approach that considers the impact of certain MNE interventions on, not just labour outcomes but also environmental outcomes. This will subsequently broaden analyses that have dealt with the environmental aspects of sustainability in isolation, to address how firms manage their triple bottom line by balancing social, environmental, and economic objectives. Furthermore, as MNEs respond to varying environmental pressures from both domestic and international regulatory regimes, scholarly work in this area would build further lines of inquiry into the effect institutional dynamics have on firms.

\subsection{Negative impacts of multinational enterprises}

When considering social value creation in MNEs, critical perspectives highlight the negative impacts of firm behaviour. Within IB journals, the primary focus is on corruption. However, future research would benefit from drawing on studies outside of business and management that, for example, have examined the negative health impacts of firm activities. By accounting for negative firm impacts, further knowledge on the firm-level factors that undermine social value creation could be gathered. This would build more holistic representations of responsible business behaviour, whilst providing more critical perspectives on the role MNEs could play in fostering equitable futures. 


\section{Conclusion}

As MNEs participate more and more in complex, globally integrated production networks, the social and environmental challenges facing international governments and their respective communities are becoming increasingly apparent and pertinent for MNEs. These pressures have been heightened as multilateral institutions have established global agendas for business participation in human rights and sustainable development. Due to its intrinsic focus on global labour and production, IB scholarship is ideally situated to account for these new challenges and build future research streams looking at how MNEs might confront these challenges (Buckley et al., 2017; Rygh, 2019). However, as this study has shown, such endeavours must go beyond disciplinary silos, to account for the complex, systematic nature of the question of how global development goals can be achieved.

While IB journals represent the second-largest field home to publications related to the social value creation of MNEs (Table IV), it only accounts for 12 per cent of the sample. Although this can partially be explained by IB scholars also publishing in journals affiliated to other fields, the point can nevertheless be made that, if the IB discipline wishes to contribute more to the grand challenges debate, IB journals need to dedicate more space to social-value-related publications. Furthermore, as grand challenges related research is more difficult to conduct, may take longer and often requires non-mainstream research methods, universities may need to re-examine their performance management practices. Without significant systemic changes at journal and university management levels one could argue that researchers who are determined to contribute to the grand challenges agenda are often penalised for doing so within business and management studies (Mingers and Willmott, 2013; Willmott, 1995, 2011). Of course, one could argue that scholars can publish their work in business ethics and sustainability related journals. However, most of those journals do not tend to feature very high in journal rankings that many universities use to judge the academic standing of their researchers by (Tüselmann et al., 2016).

As is the case with most studies, this paper is not free from limitations. To focus the review on social value creation in the context of MNEs, the search was limited to studies explicitly mentioning MNEs (and synonyms) in their title, abstract or key words. Also, the list of key words targeted at identifying studies on social value creation did not include all of its facets. For example, "bottom of the pyramid", "corporate political activity", and "nonmarket strategies" did not feature among the search terms. Nevertheless, these themes emerged from the analysis. Future studies may wish to build on our insights and design even more elaborate search strategies. Such future research would be well advised to consider an iterative approach to database construction, to remedy any shortcomings of the initial search strategy.

\section{Notes}

1. TS stands for topic in the Web of Science.

2. The ISSN numbers correspond to the following business ethics journals: Business and Society, Business and Society Review, Journal of Business Ethics, Leadership and Business Ethics, Business Ethics - A European Review, Business Ethics Quarterly, International Journal of Business and Society, Corporate Responsibility and Environmental Management, Society and Business Review, Social Responsibility Journal, African Journal of Business Ethics, Journal of Global Responsibility, Key Initiatives in Corporate Social Responsibility: Global Dimension of CSR in Corporate Entities, Asian Journal of Business Ethics.
Social value creation of MNEs 


\section{CPOIB}

16,1

28

\section{References}

Accorsi, R., Versari, L. and Manzini, R. (2015), "Glass vs. Plastic: life cycle assessment of extra-virgin olive oil bottles across global supply chains”, Sustainability, Vol. 7 No. 3, pp. 2818-2840, doi: 10.3390/su7032818.

Achabou, M.A., Dekhili, S. and Hamdoun, M. (2017), "Environmental upgrading of developing country firms in global value chains", Business Strategy and the Environment, Vol. 26 No. 2, pp. 224-238, doi: 10.1002/bse.1911.

Acquaye, A.A., Yamoah, F.A. and Feng, K.S. (2015), "An integrated environmental and fairtrade labelling scheme for product supply chains", International Journal of Production Economics, Vol. 164, pp. 472-483, doi: 10.1016/j.ijpe.2014.12.014.

Aguilera-Caracuel, J., Aragon-Correa, J.A., Hurtado-Torres, N.E. and Rugman, A.M. (2012), “The effects of institutional distance and headquarters' financial performance on the generation of environmental standards in multinational companies", Journal of Business Ethics, Vol. 105 No. 4, pp. 461-474, doi: 10.1007/s10551-011-0978-7.

Alam, M.S. and Natsuda, K. (2016), "The competitive factors of the bangladeshi garment industry in the post-mfa era”, Canadian Journal of Development Studies-Revue Canadienne D Etudes Du Developpement, Vol. 37 No. 3, pp. 316-336, doi: 10.1080/02255189.2016.1157457.

Alas, R. and Edwards, V. (2011), "Work-related attitudes in asia and europe: institutional approach", Engineering Economics, Vol. 22 No. 1, pp. 24-31.

Alas, R. and Wei, S. (2008), "Institutional impact on work-related values in chinese organizations", Journal of Business Ethics, Vol. 83 No. 2, pp. 297-306, doi: 10.1007/s10551-007-9620-0.

Alford, M. (2016), “Trans-scalar embeddedness and governance deficits in global production networks: crisis in South African fruit”, Geoforum, Vol. 75, pp. 52-63, doi: 10.1016/j.geoforum.2016.07.005.

Amekawa, Y. (2009), "Reflections on the growing influence of good agricultural practices in the global South", Journal of Agricultural and Environmental Ethics, Vol. 22 No. 6, pp. 531-557, doi: 10.1007/ s10806-009-9171-8.

Anaf, J., Baum, F.E., Fisher, M., Harris, E. and Friel, S. (2017), "Assessing the health impact of transnational corporations: a case study on mcdonald's australia", Globalization and Health, Vol. 13 No. 1, pp. 1-16, doi: 10.1186/s12992-016-0230-4.

Anner, M. (2017), "Monitoring workers' rights: the limits of voluntary social compliance initiatives in labor repressive regimes", Global Policy, Vol. 8, pp. 56-65, doi: 10.1111/1758-5899.12385.

Arnold, D.G. (2010), “Transnational corporations and the duty to respect basic human rights", Business Ethics Quarterly, Vol. 20 No. 3, pp. 371-399.

Arnold, D.G. and Valentin, A. (2013), "Corporate social responsibility at the base of the pyramid", Journal of Business Research, Vol. 66 No. 10, pp. 1904-1914, doi: 10.1016/j.jbusres.2013.02.012.

Azizi, S. and Jamali, D. (2016), "Csr in Afghanistan: a global CSR agenda in areas of limited statehood", South Asian Journal of Global Business Research, Vol. 5 No. 2, pp. 165-189, doi: 10.1108/sajgbr01-2015-0007.

Bair, J. and Palpacuer, F. (2015), "Csr beyond the corporation: contested governance in global value chains", Global Networks-a Journal of Transnational Affairs, Vol. 15 No. s1, pp. S1-S19, doi: 10.1111/glob.12085.

Barrientos, S. (2014), "Gendered global production networks: analysis of cocoa-chocolate sourcing", Regional Studies, Vol. 48 No. 5, pp. 791-803, doi: 10.1080/00343404.2013.878799.

Barrientos, S., Knorringa, P., Evers, B., Visser, M. and Opondo, M. (2016), "Shifting regional dynamics of global value chains: implications for economic and social upgrading in African horticulture", Environment and Planning A: Economy and Space, Vol. 48 No. 7, pp. 1266-1283, doi: 10.1177/ $0308518 x 15614416$.

Baum, F.E., Sanders, D.M., Fisher, M., Anaf, J., Freudenberg, N., Friel, S. and Sen, A. (2016), “Assessing the health impact of transnational corporations: its importance and a framework", Globalization and Health, Vol. 12 No. 1, pp. 1-7, doi: 10.1186/s12992-016-0164-x. 
Beckman, T., Colwell, A. and Cunningham, P.H. (2009), "The emergence of corporate social responsibility in Chile: the importance of authenticity and social networks", Journal of Business Ethics, Vol. 86 No. 2, pp. 191-206, doi: 10.1007/s10551-009-0190-1.

Bek, D., Binns, T. and Nel, E. (2013), "Wild flower harvesting on South Africa's Agulhas plain: a mechanism for achieving sustainable local economic development?", Sustainable Development, Vol. 21 No. 5, pp. 281-293, doi: 10.1002/sd.499.

Belal, A. and Owen, D.L. (2015), "The rise and fall of stand-alone social reporting in a multinational subsidiary in Bangladesh a case study", Accounting, Auditing and Accountability Journal, Vol. 28 No. 7, pp. 1160-1192, doi: 10.1108/aaaj-08-2013-1443.

Bell, E., Taylor, S. and Driscoll, C. (2012), "Varieties of organizational soul: the ethics of belief in organizations", Organization, Vol. 19 No. 4, pp. 425-439, doi: 10.1177/1350508411411759.

Bendixen, M. and Abratt, R. (2007), "Corporate identity, ethics and reputation in supplier-buyer relationships", Journal of Business Ethics, Vol. 76 No. 1, pp. 69-82, doi: 10.1007/s10551-006-9273-4.

Binh, T.T.C. and Linh, N.M. (2013), "Supplier system and knowledge transfer within the production networks of electronics MNCs in Vietnam", Asian Journal of Technology Innovation, Vol. 21 No. 1, pp. 119-138, doi: 10.1080/19761597.2013.819237.

Bondy, K., Matten, D. and Moon, J. (2008), "Multinational corporation codes of conduct: Governance tools for corporate social responsibility? Corporate governance-an", Corporate Governance: An International Review, Vol. 16 No. 4, pp. 294-311, doi: 10.1111/j.1467-8683.2008.00694.x.

Bondy, K., Moon, J. and Matten, D. (2012), "An institution of corporate social responsibility (CSR) in multi-national corporations (MNCs): form and implications", Journal of Business Ethics, Vol. 111 No. 2, pp. 281-299, doi: 10.1007/s10551-012-1208-7.

Bostrom, M. (2015), "Between monitoring and trust: Commitment to extended upstream responsibility", Journal of Business Ethics, Vol. 131 No. 1, pp. 239-255, doi: 10.1007/s10551-014-2277-6.

Bowen, R.H. (1953), Social Responsibilities of the Businessman, Harper, New York, NY.

Brammer, S.J., Pavelin, S. and Porter, L.A. (2006), "Corporate social performance and geographical diversification”, Journal of Business Research, Vol. 59 No. 9, pp. 1025-1034, doi: 10.1016/j. jbusres.2006.04.001.

Brammer, S.J., Pavelin, S. and Porter, L.A. (2009), "Corporate charitable giving, multinational companies and countries of concern", Journal of Management Studies, Vol. 46 No. 4, pp. 575-596, doi: 10.1111/j.1467-6486.2008.00827.x.

Brandi, C.A. (2017), "Sustainability standards and sustainable development - synergies and trade-offs of transnational governance", Sustainable Development, Vol. 25 No. 1, pp. 25-34, doi: 10.1002/sd.1639.

Bridge, G. (2008), "Global production networks and the extractive sector: governing resource-based development”, Journal of Economic Geography, Vol. 8 No. 3, pp. 389-419, doi: 10.1093/jeg/lbn009.

Bridge, G. and Bradshaw, M. (2017), "Making a global gas market: territoriality and production networks in liquefied natural gas", Economic Geography, Vol. 93 No. 3, pp. 215-240, doi: 10.1080/ 00130095.2017.1283212.

Brunori, G., Galli, F., Barjolle, D., van Broekhuizen, R., Colombo, L., Giampietro, M. and Touzard, J.M. (2016), "Are local food chains more sustainable than global food chains? Considerations for assessment”, Sustainability, Vol. 8 No. 5, pp. 1-27, doi: 10.3390/su8050449.

$\mathrm{Bu}$, Q.X. (2015), "Chinese multinational companies in Africa: the human rights discourse", African Journal of Legal Studies, Vol. 8 No. 1-2, pp. 33-86, doi: 10.1163/17087384-12342061.

Buckley, P.J., Doh, J.P. and Benischke, M.H. (2017), "Towards a renaissance in international business research? Big questions, grand challenges, and the future of IB scholarship", Journal of International Business Studies, Vol. 48 No. 9, pp. 1045-1064, doi: 10.1057/s41267-017-0102-z.

Buldybayeva, G. (2014), "Both sides of csr practice: a case from oil and gas industry in Kazakhstan", Acta Polytechnica Hungarica, Vol. 11 No. 2, pp. 229-248. 


\section{CPOIB} 16,1

Burchell, J. and Cook, J. (2013), "Sleeping with the enemy? Strategic transformations in business-NGO relationships through stakeholder dialogue", Journal of Business Ethics, Vol. 113 No. 3, pp. 505-518, doi: 10.1007/s10551-012-1319-1.

Busse, C., Kach, A.P. and Bode, C. (2016), "Sustainability and the false sense of legitimacy: how institutional distance augments risk in global supply chains", Journal of Business Logistics, Vol. 37 No. 4, pp. 312-328, doi: 10.1111/jbl.12143.

Butler, N. (2000), “Companies in international relations”, Survival, Vol. 42 No. 1, pp. 149-164, doi: 10.1093/survival/42.1.149.

Calderon-Cuadrado, R., Alvarez-Arce, J.L., Rodriguez-Tejedo, I. and Salvatierra, S. (2009), "Ethics hotlines" in transnational companies: a comparative study", Journal of Business Ethics, Vol. 88 No. 1, pp. 199-210, doi: 10.1007/s10551-009-0110-4.

Cambra-Fierro, J., Polo-Redondo, Y. and Wilson, A. (2008), "The influence of an organisation's corporate values on employees personal buying behaviour", Journal of Business Ethics, Vol. 81 No. 1, pp. 157-167, doi: 10.1007/s10551-007-9486-1.

Campbell, J.T., Eden, L. and Miller, S.R. (2012), "Multinationals and corporate social responsibility in host countries: does distance matter?", Journal of International Business Studies, Vol. 43 No. 1, pp. 84-106, doi: 10.1057/jibs.2011.45.

Cannizzaro, A.P. and Weiner, R.J. (2015), "Multinational investment and voluntary disclosure: projectlevel evidence from the petroleum industry", Accounting Organizations and Society, Vol. 42, pp. 32-47, doi: 10.1016/j.aos.2015.01.002.

Cantani, A. (2009), "Benefits and concerns associated with biotechnology-derived foods: can additional research reduce children health risks?", European Review for Medical and Pharmacological Sciences, Vol. 13 No. 1, pp. 41-50.

Carey, M., French, A. and O’Brien, E. (2012), “Unintended effects of technology on climate change adaptation: an historical analysis of water conflicts below Andean glaciers", Journal of Historical Geography, Vol. 38 No. 2, pp. 181-191, doi: 10.1016/j.jhg.2011.12.002.

Chai, Q.Q., Cheung, C.W.M. and Kwong, C. (2016), "Early global trotters and their entrepreneurial employment practices a case study of the colonial Hong Kong government, 1845-1850", Journal of Entrepreneurship in Emerging Economies, Vol. 8 No. 3, pp. 378-384, doi: 10.1108/jeee-07-20160022.

Chakrabarty, S. and Bass, A.E. (2015), "Comparing virtue, consequentialist, and deontological ethics-based corporate social responsibility: mitigating microfinance risk in institutional voids", Journal of Business Ethics, Vol. 126 No. 3, pp. 487-512, doi: 10.1007/s10551-0131963-0.

Chang, D.R., Jang, J., Lee, E.Y., Lee, H. and Chang, B. (2017), "When a good company transgresses: a study of the influences of csr, moral decoupling, and ethnocentrism", Journal of Global Fashion Marketing, Vol. 8 No. 1, pp. 40-53, doi: 10.1080/20932685.2016.1255853.

Chiu, T.K. and Wang, Y.H. (2015), "Determinants of social disclosure quality in Taiwan: an application of stakeholder theory", Journal of Business Ethics, Vol. 129 No. 2, pp. 379-398, doi: 10.1007/ s10551-014-2160-5.

Chowdhury, R. (2017), "The rana plaza disaster and the complicit behavior of elite NGOs", Organization, Vol. 24 No. 6, pp. 938-949, doi: 10.1177/1350508417699023.

Christian, M. (2016a), "Kenya's tourist industry and global production networks: gender, race and inequality", Global Networks-a Journal of Transnational Affairs, Vol. 16 No. 1, pp. 25-44.

Christian, M. (2016b), "Tourism global production networks and uneven social upgrading in Kenya and Uganda”, Tourism Geographies, Vol. 18 No. 1, pp. 38-58, doi: 10.1080/14616688.2015.1116596.

Ciliberti, F., de Groot, G., de Haan, J. and Pontrandolfo, P. (2009), "Codes to coordinate supply chains: SMEs' experiences with sa8000”, Supply Chain Management: An International Journal, Vol. 14 No. 2, pp. 117-127, doi: 10.1108/13598540910941984. 
Clark, R. (1992), "Multinational corporate-investment and womens participation in higher-education in noncore nations", Sociology of Education, Vol. 65 No. 1, pp. 37-47, doi: 10.2307/2112691.

Cohen, J., Krishnamoorthy, G. and Wright, A.M. (2002), "Corporate governance and the audit process*", Contemporary Accounting Research, Vol. 19 No. 4, pp. 573-594, doi: 10.1506/983m-epxg-4y0r-j9yk.

Social value creation of MNEs

Collins, D. (2009), "The failure of a socially responsive gold mining MNC in El Salvador: ramifications of NGO mistrust", Journal of Business Ethics, Vol. 88 No. 2, pp. 245-268, doi: 10.1007/s10551-009-0288-5.

Compa, L. (2002), "Pursuing international labour rights in us courts - new uses for old tools", Relations Industrielles-Industrial Relations, Vol. 57 No. 1, pp. 48-76.

Crilly, D., Ni, N. and Jiang, Y.W. (2016), "Do-no-harm versus do-good social responsibility: attributional thinking and the liability of foreignness", Strategic Management Journal, Vol. 37 No. 7 , pp. 1316-1329, doi: 10.1002/smj.2388.

Crisan-Mitra, C., Dinu, V., Postelnicu, C. and Dabija, D.C. (2016), "Corporate practice of sustainable development on an emerging market", Transformations in Business and Economics, Vol. 15 No. 1, pp. 228-243.

Cruz, J.M. (2013a), "Mitigating global supply chain risks through corporate social responsibility", International Journal of Production Research, Vol. 51 No. 13, pp. 3995-4010, doi: 10.1080/ 00207543.2012 .762134$.

Cruz, J.M. (2013b), "Modeling the relationship of globalized supply chains and corporate social responsibility", Journal of Cleaner Production, Vol. 56, pp. 73-85, doi: 10.1016/j.jclepro.2011.09.013.

Cruz, L.B. and Pedrozo, E.A. (2009), "Corporate social responsibility and green management relation between headquarters and subsidiary in multinational corporations", Management Decision, Vol. 47 No. 7, pp. 1174-1199, doi: 10.1108/00251740910978368.

Dam, L. and Scholtens, B. (2008), "Environmental regulation and MNEs location: does csr matter?", Ecological Economics, Vol. 67 No. 1, pp. 55-65, doi: 10.1016/j.ecolecon.2007.11.007.

Dam, L. and Scholtens, B. (2012), "The curse of the haven: the impact of multinational enterprise on environmental regulation", Ecological Economics, Vol. 78, pp. 148-156, doi: 10.1016/j. ecolecon.2012.04.011.

D’Amelio, M., Garrone, P. and Piscitello, L. (2016), "Can multinational enterprises light up developing countries? Evidences from the access to electricity in Sub-Saharan Africa”, World Development, Vol. 88, pp. 12-32, doi: 10.1016/j.worlddev.2016.06.018.

Darendeli, I.S. and Hill, T.L. (2016), "Uncovering the complex relationships between political risk and MNE firm legitimacy: insights from Libya”, Journal of International Business Studies, Vol. 47 No. 1, pp. 68-92, doi: 10.1057/jibs.2015.27.

de Lange, D.E., Armanios, D., Delgado-Ceballos, J. and Sandhu, S. (2016), "From foe to friend: complex mutual adaptation of multinational corporations and nongovernmental organizations", Business and Society, Vol. 55 No. 8, pp. 1197-1228, doi: 10.1177/ 0007650314568537.

Deegan, C. and Islam, M.A. (2014), "An exploration of NGO and media efforts to influence workplace practices and associated accountability within global supply chains", British Accounting Review, Vol. 46 No. 4, pp. 397-415, doi: 10.1016/j.bar.2014.10.002.

Dehnen, V. (2013), "Transnational alliances for negotiating international framework agreements: Power relations and bargaining processes between global union federations and European works councils", British Journal of Industrial Relations, Vol. 51 No. 3, pp. 577-600, doi: 10.1111/bjir.12038.

Devinney, T.M. (2011), "Social responsibility, global strategy, and the multinational enterprise: global monitory democracy and the meaning of place and space", Global Strategy Journal, Vol. 1 Nos 3/4, pp. 329-344, doi: 10.1111/j.2042-5805.2011.00021.x.

Dobson, J. (1992), "Ethics in the transnational corporation - the moral buck stops where", Journal of Business Ethics, Vol. 11 No. 1, pp. 21-27, doi: 10.1007/bf00871988. 
CPOIB 16,1

Doh, J.P. and Lucea, R. (2013), "So close yet so far: integrating global strategy and nonmarket research", Global Strategy Journal, Vol. 3 No. 2, pp. 171-194, doi: 10.1111/j.2042-5805.2013.01053.x.

Donaghey, J., Reinecke, J., Niforou, C. and Lawson, B. (2014), "From employment relations to consumption relations: balancing labor governance in global supply chains", Human Resource Management, Vol. 53 No. 2, pp. 229-252, doi: 10.1002/hrm.21552.

Drebes, M.J. (2016), "Including the 'other': power and postcolonialism as underrepresented perspectives in the discourse on corporate social responsibility", Critical Sociology, Vol. 42 No. 1, pp. 105-121, doi: 10.1177/0896920513509824.

Driffield, N., Jones, C. and Crotty, J. (2013), "International business research and risky investments, an analysis of FDI in conflict zones", International Business Review, Vol. 22 No. 1, pp. 140-155, doi: 10.1016/j.ibusrev.2012.03.001.

Dura, C.C., Driga, I. and Isac, C. (2017), "Environmental reporting by oil and gas multinationals from Russia and Romania: a comparative analysis", Environmental Engineering and Management Journal, Vol. 16 No. 6, pp. 1269-1274.

Durand, R. and Jacqueminet, A. (2015), "Peer conformity, attention, and heterogeneous implementation of practices in MNEs", Journal of International Business Studies, Vol. 46 No. 8, pp. 917-937, doi: 10.1057/jibs.2015.21.

Egels-Zanden, N. (2009), "TNC motives for signing international framework agreements: a continuous bargaining model of stakeholder pressure", Journal of Business Ethics, Vol. 84 No. 4, pp. 529-547, doi: doi: 10.1007/s10551-008-9722-3.

Egels-Zanden, N. and Hyllman, P. (2006), "Exploring the effects of union-NGO relationships on corporate responsibility: the case of the Swedish clean clothes campaign", Journal of Business Ethics, Vol. 64 No. 3, pp. 303-316, doi: 10.1007/s10551-005-5497-y.

El Ghoul, S., Guedhami, O. and Kim, Y. (2017), "Country-level institutions, firm value, and the role of corporate social responsibility initiatives", Journal of International Business Studies, Vol. 48 No. 3, pp. 360-385, doi: 10.1057/jibs.2016.4.

Elkington, J. and Braun, S. (2013), "Breakthrough business leaders, market revolutions”, Volans, pp. 1-64.

Fazey, J., Schapke, N., Caniglia, G., Patterson, J., Hultman, J., van Mierlo, B. and Wyborn, C. (2018), "Ten essentials for action-oriented and second order energy transitions, transformations and climate change research", Energy Research and Social Science, Vol. 40, pp. 54-70, doi: 10.1016/j. erss.2017.11.026.

Fernandez, V.R. (2015), "Global value chains in global political networks: tool for development or neoliberal device?”, Review of Radical Political Economics, Vol. 47 No. 2, pp. 209-230, doi: 10.1177/ 0486613414532769.

Fiksel, J. (2001), "Emergence of a sustainable business community", Pure and Applied Chemistry, Vol. 73 No. 8, pp. 1265-1268, doi: 10.1351/pac200173081265.

Filatotchev, I. and Nakajima, C. (2014), “Corporate governance, responsible managerial behavior, and corporate social responsibility: organizational efficiency versus organizational legitimacy?", Academy of Management Perspectives, Vol. 28 No. 3, pp. 289-306, doi: 10.5465/ amp.2014.0014.

Forcadell, F.J. and Aracil, E. (2017), "Sustainable banking in Latin American developing countries: Leading to (mutual) prosperity”, Business Ethics: A European Review, Vol. 26 No. 4, pp. 382-395, doi: 10.1111/beer.12161.

Franz, M. and Hassler, M. (2010), "The value of commodity biographies: integrating tribal farmers in India into a global organic agro-food network", Area, Vol. 42 No. 1, pp. 25-34, doi: 10.1111/j.14754762.2009.00893.x.

Frynas, J.G. (2005), "The false developmental promise of corporate social responsibility: evidence from multinational oil companies", International Affairs, Vol. 81 No. 3, pp. 581, doi: 10.1111/j.14682346.2005.00470.x. 
Frynas, J.G. (2010), "Corporate social responsibility and societal governance: lessons from transparency in the oil and gas sector", Journal of Business Ethics, Vol. 93 No. 2, pp. 163-179, doi: 10.1007/s10551-010-0559-1.

Gaffney, N., Karst, R. and Clampit, J. (2016), "Emerging market MNE cross-border acquisition equity participation: the role of economic and knowledge distance", International Business Review, Vol. 25 No. 1, pp. 267-275, doi: 10.1016/j.ibusrev.2015.05.005.

Garcia-Castro, R. and Francoeur, C. (2016), "When more is not better: complementarities, costs and contingencies in stakeholder management”, Strategic Management Journal, Vol. 37 No. 2, pp. 406-424, doi: 10.1002/smj.2341.

Garcia-Rodriguez, F.J., Garcia-Rodriguez, J.L., Castilla-Gutierrez, C. and Major, S.A. (2013), "Corporate social responsibility of oil companies in developing countries: from altruism to business strategy", Corporate Social Responsibility and Environmental Management, Vol. 20 No. 6, pp. 371-384, doi: 10.1002/csr.1320.

George, G., Howard-Grenville, J., Joshi, A. and Tihanyi, L. (2016), "Understanding and tackling societal grand challenges through management research", Academy of Management Journal, Vol. 59 No. 6, pp. 1880-1895, doi: 10.5465/amj.2016.4007.

Getz, K.A. and Oetzel, J. (2009), "Mne strategic intervention in violent conflict: variations based on conflict characteristics", Journal of Business Ethics, Vol. 89 No. 4, pp. 375-386, doi: 10.1007/ s10551-010-0412-6.

Gibassier, D. and Schaltegger, S. (2015), "Carbon management accounting and reporting in practice a case study on converging emergent approaches", Sustainability Accounting, Management and Policy Journal, Vol. 6 No. 3, pp. 340-365, doi: 10.1108/sampj-02-2015-0014.

Gifford, B. and Kestler, A. (2008), "Toward a theory of local legitimacy by MNEs in developing nations: Newmont mining and health sustainable development in Peru", Journal of International Management, Vol. 14 No. 4, pp. 340-352, doi: 10.1016/j.intman.2007.09.005.

Gilbert, J. and Wisner, J. (2010), "Mattel, lead paint, and magnets: ethics and supply chain management", Ethics and Behavior, Vol. 20 No. 1, pp. 33-46, doi: 10.1080/10508420903482491.

Giraudo, J.P. (2005), "Charitable contributions and the fcpa: schering-plough and the increasing scope of sec enforcement”, Business Lawyer, Vol. 61 No. 1, pp. 135-154.

Giri, A.K. and Singh, S.P. (2016), "Labour standards in global value chains in India: the case of handknotted carpet manufacturing cluster", Asian Journal of Business Ethics, Vol. 5 Nos 1/2, pp. 37-52, doi: 10.1007/s13520-016-0052-8.

Giuliani, E. and Macchi, C. (2014), "Multinational corporations economic and human rights impacts on developing countries: a review and research agenda", Cambridge Journal of Economics, Vol. 38 No. 2, pp. 479-517, doi: 10.1093/cje/bet060.

Gold, S., Hahn, R. and Seuring, S. (2013), "Sustainable supply chain management in "base of the pyramid' food projects-a path to triple bottom line approaches for multinationals?", International Business Review, Vol. 22 No. 5, pp. 784-799, doi: 10.1016/j.ibusrev.2012.12.006.

Golini, R., Longoni, A. and Cagliano, R. (2014), "Developing sustainability in global manufacturing networks: the role of site competence on sustainability performance", International Journal of Production Economics, Vol. 147, pp. 448-459, doi: 10.1016/j.jpe.2013.06.010.

Gonzalez, A. (2016), "Poverty, oil and corruption: the need for a quad-sector development partnership (qsdp) in Nigeria's Niger Delta”, Development Policy Review, Vol. 34 No. 4, pp. 509-538, doi: 10.1111/ dpr.12164.

Griffis, S.E., Autry, C.W., Thornton, L.M. and ben Brik, A. (2014), “Assessing antecedents of socially responsible supplier selection in three global supply chain contexts", Decision Sciences, Vol. 45 No. 6, pp. 1187-1215, doi: 10.1111/deci.12101.

Gruber, V. and Schlegelmilch, B.B. (2015), "Mnes' regional headquarters and their csr agenda in the African context", International Marketing Review, Vol. 32 No. 5, pp. 576-602, doi: 10.1108/imr-032014-0100. 


\section{CPOIB} 16,1

Gupta, S. (2017), "Returns on social development initiatives of MNEs: issues and perspectives", Qualitative Market Research: An International Journal, Vol. 20 No. 2, pp. 126-146, doi: 10.1108/ qmr-01-2017-0004.

Gupta, S. and Srivastav, P. (2016), "Despite unethical retail store practices, consumers at the bottom of the pyramid continue to be loyal", International Review of Retail Distribution and Consumer Research, Vol. 26 No. 1, pp. 75-94, doi: 10.1080/09593969.2015.1050053.

Ha-Brookshire, J., McAndrews, L., Kim, J., Freeman, C., Jin, B., Norum, P., LeHew, M., Karpova, E., Hassall, L. and Marcketti, S. (2017), "Moral education for sustainable development: exploring morally challenging business situations within the global supply chain context", Sustainability, Vol. 9 No. 9, doi:, doi: 10.3390/su9091641.

Haddock-Millar, J., Sanyal, C. and Muller-Camen, M. (2016), "Green human resource management: a comparative qualitative case study of a United States multinational corporation", International Journal of Human Resource Management, Vol. 27 No. 2, pp. 192-211, doi: 10.1080/09585192.2015.1052087.

Hadjikhani, A., Lee, J.W. and Park, S. (2016), "Corporate social responsibility as a marketing strategy in foreign markets the case of Korean MNCs in the chinese electronics market", International Marketing Review, Vol. 33 No. 4, pp. 530-554, doi: 10.1108/imr-03-2014-0104.

Hall, J., Matos, S.V. and Martin, M.J.C. (2014), "Innovation pathways at the base of the pyramid: establishing technological legitimacy through social attributes", Technovation, Vol. 34 Nos 5/6, pp. 284-294, doi: 10.1016/j.technovation.2013.12.003.

Halter, M.V., de Arruda, M.C.C. and Halter, R.B. (2009), “Transparency to reduce corruption?”, Journal of Business Ethics, Vol. 84 No. 3, pp. 373-385, doi: 10.1007/s10551-009-0198-6.

Halvorsen, T. and Jakobsen, J. (2013), "Democrats, republicans - or both? An empirical analysis of the effects of the composition of state governments on fdi, 1977-2004", International Interactions, Vol. 39 No. 2, pp. 167-191, doi: 10.1080/03050629.2013.768470.

Hanekom, D. and Luiz, J.M. (2017), "The impact of multinational enterprises on public governance institutions in areas of limited statehood", Management Decision, Vol. 55 No. 8, pp. 1736-1748, doi: 10.1108/md-11-2016-0774.

Hartlieb, S. and Jones, B. (2009), "Humanising business through ethical labelling: progress and paradoxes in the UK", Journal of Business Ethics, Vol. 88 No. 3, pp. 583-600, doi: 10.1007/s10551009-0125.x

Hartman, L., Werhane, P. and Clark, K.L. (2011), “Development, poverty and business ethics”, Universia Business Review, Vol. 30, pp. 96-108.

Hartog, R. (1993), "Essential and nonessential drugs marketed by the 20 largest European pharmaceutical companies in developing-countries", Social Science and Medicine, Vol. 37 No. 7 , pp. 897-904, doi: 10.1016/0277-9536(93)90144-s.

Harzing, A.-W. (Producer). (2017), "Journal quality list", available at: http:/harzing.com (accsseced 20 October 2018).

Hasan, R. (2013), "Reflections on foreign direct investment and development with reference to nongovernmental organizations and corporate social responsibility", Critical Sociology, Vol. 39 No. 1, pp. 37-43, doi: 10.1177/0896920511414067.

Hayhurst, L.M.C. (2011), "Corporatising sport, gender and development: postcolonial IR feminisms, transnational private governance and global corporate social engagement", Third World Quarterly, Vol. 32 No. 3, pp. 531-549, doi: 10.1080/01436597.2011.573944.

Helfen, M.O., Schussler, E. and Stevis, D. (2016), "Translating European labor relations practices to the United States through global framework agreements? German and Swedish multinationals compared", Ilr Review, Vol. 69 No. 3, pp. 631-655, doi: 10.1177/0019793915624090.

Helin, S. and Babri, M. (2015), "Travelling with a code of ethics: a contextual study of a Swedish MNC auditing a chinese supplier", Journal of Cleaner Production, Vol. 107, pp. 41-53, doi: 10.1016/j. jclepro.2014.08.056. 
Hemphill, T.A. and Kelley, K.J. (2016), "Socially responsible global supply chains the human rights promise", Journal of Global Responsibility, Vol. 7 No. 2, pp. 163-180, doi: 10.1108/jgr05-2016-0013.

Hemphill, T.A. and Lillevik, W. (2011), "The global economic ethic manifesto: implementing a moral values foundation in the multinational enterprise", Journal of Business Ethics, Vol. 101 No. 2, pp. 213-230, doi: 10.1007/s10551-010-0718-4.

Henderson, J., Dicken, P., Hess, M., Coe, N. and Yeung, H.W.C. (2002), "Global production networks and the analysis of economic development", Review of International Political Economy, Vol. 9 No. 3, pp. 436-464, doi: 10.1080/09692290210150842.

Horner, R. (2016), "Pharmaceuticals and the global South: a healthy challenge for development theory?”, Geography Compass, Vol. 10 No. 9, pp. 363-377, doi: 10.1111/gec3.12277.

Horner, R. (2017), "Beyond facilitator? State roles in global value chains and global production networks", Geography Compass, Vol. 11 No. 2, pp. 1-13, doi: 10.1111/gec3.12307.

Hughes, A., Wrigley, N. and Buttle, M. (2008), "Global production networks, ethical campaigning, and the embeddedness of responsible governance", Journal of Economic Geography, Vol. 8 No. 3, pp. 345-367, doi: 10.1093/jeg/lbn004.

Husted, B.W. and Allen, D.B. (2006), "Corporate social responsibility in the multinational enterprise: strategic and institutional approaches", Journal of International Business Studies, Vol. 37 No. 6, pp. 838-849, doi: 10.1057/palgrave.jibs.8400227.

Husted, B.W., Montiel, I. and Christmann, P. (2016), "Effects of local legitimacy on certification decisions to global and national csr standards by multinational subsidiaries and domestic firms", Journal of International Business Studies, Vol. 47 No. 3, pp. 382-397, doi: 10.1057/jibs.2016.3.

Ibanez, L. (2015), "Beyond inclusiveness: institutions, cooperation and rural development", Canadian Journal of Development Studies-Revue Canadienne D Etudes Du Developpement, Vol. 36 No. 4, pp. 499-515, doi: 10.1080/02255189.2015.1098592.

Idemudia, U. (2014a), "Oil companies and sustainable community development in the Niger Delta, Nigeria: the issue of reciprocal responsibility and its implications for corporate citizenship theory and practice”, Sustainable Development, Vol. 22 No. 3, pp. 177-187, doi: $10.1002 / \mathrm{sd} .538$.

Idemudia, U. (2014b), "Oil multinational companies as money makers and peace makers: lessons from Nigeria”, Corporate Social Responsibility and Sustainability: Emerging Trends in Developing Economies, Vol. 8, pp. 191-213. doi: 10.1108/s2043-905920140000008011

Imbun, B.Y. (2007), "Cannot manage without the 'significant other': mining, corporate social responsibility and local communities in Papua New guinea", Journal of Business Ethics, Vol. 73 No. 2, pp. 177-192, doi: 10.1007/s10551-006-9189-z.

Inman, P. (2016), "Study: Big corporations dominate list of world's top economic entities", www. theguardian.com/business/2016/sep/12/global-justice-now-study-multinational-businesseswalmart-apple-shell

Iriyama, A., Kishore, R. and Talukdar, D. (2016), "Playing dirty or building capability? Corruption and $\mathrm{hr}$ training as competitive actions to threats from informal and foreign firm rivals", Strategic Management Journal, Vol. 37 No. 10, pp. 2152-2173, doi: 10.1002/smj.2447.

Islam, M.A. and Deegan, C. (2010), "Media pressures and corporate disclosure of social responsibility performance information: a study of two global clothing and sports retail companies", Accounting and Business Research, Vol. 40 No. 2, pp. 131-148, doi: 10.1080/00014788.2010.9663388.

Jackson, K.T. (2000), "The polycentric character of business ethics decisionmaking in international contexts", Journal of Business Ethics, Vol. 23 No. 1, pp. 123-143, doi: 10.1023/a:1006239415584.

Jamali, D. (2010a), "The csr of MNC subsidiaries in developing countries: global, local, substantive or diluted?", Journal of Business Ethics, Vol. 93 No. 2, pp. 181-200, doi: 10.1007/s10551-010$0560-8$. 
CPOIB 16,1

Jamali, D. (2010b), "MNCs and international accountability standards through an institutional lens: evidence of symbolic conformity or decoupling", Journal of Business Ethics, Vol. 95 No. 4, pp. 617-640, doi: 10.1007/s10551-010-0443-z.

Jamali, D., Zanhour, M. and Keshishian, T. (2009), "Peculiar strengths and relational attributes of smes in the context of csr", Journal of Business Ethics, Vol. 87 No. 3, pp. 355-377, doi: 10.1007/s10551008-9925-7.

Jorgensen, M.S. and Milanez, B. (2017), "Downstream management practices of transnational companies in institutionally vulnerable countries: export and use of hazardous products", Journal of Cleaner Production, Vol. 140, pp. 1095-1104, doi: 10.1016/j.jclepro.2016.10.060.

Joutsenvirta, M. and Vaara, E. (2009), "Discursive (de)legitimation of a contested Finnish greenfield investment project in Latin America", Scandinavian Journal of Management, Vol. 25 No. 1, pp. 85-96, doi: 10.1016/j.scaman.2008.11.002.

Karavias, M. (2015), "Shared responsibility and multinational enterprises", Netherlands International Law Review, Vol. 62 No. 1, pp. 91-117, doi: 10.1007/s40802-015-0008-z.

Karp, D.J. (2009), “Transnational corporations in 'bad states': human rights duties, legitimate authority and the rule of law in international political theory", International Theory, Vol. 1 No. 1, pp. 87-118, doi: 10.1017/s1752971909000074.

Kauppi, K. and Hannibal, C. (2017), "Institutional pressures and sustainability assessment in supply chains”, Supply Chain Management: An International Journal, Vol. 22 No. 5, pp. 458-472, doi: 10.1108/scm-01-2017-0004.

Keig, D.L., Brouthers, L.E. and Marshall, V.B. (2015), "Formal and informal corruption environments and multinational enterprise social irresponsibility", Journal of Management Studies, Vol. 52 No. 1, pp. 89-116, doi: 10.1111/joms.12102.

Kelly, J.E. (2004), "Solidarity and subsidiarity: 'organizing principles' for corporate moral leadership in the new global economy", Journal of Business Ethics, Vol. 52 No. 3, pp. 283-295, doi: 10.1023/B: BUSI.0000037479.11370.cd.

Khan, Z., Lew, Y.K. and Il Park, B. (2015), "Institutional legitimacy and norms-based csr marketing practices insights from mncs operating in", A Developing Economy. International Marketing Review, Vol. 32 No. 5, pp. 463-491, doi: 10.1108/imr-01-2014-0017.

Kim, C.H., Amaeshi, K., Harris, S. and Suh, C.J. (2013), "Csr and the national institutional context: the case of South Korea”, Journal of Business Research, Vol. 66 No. 12, pp. 2581-2591, doi: 10.1016/j. jbusres.2012.05.015.

Kim, J. and Jeon, Y. (2015), "Dividend policy and corporate social responsibility: a comparative analysis of multinational enterprise subsidiaries and domestic firms in Korea”, Emerging Markets Finance and Trade, Vol. 51 No. 2, pp. 306-319, doi: 10.1080/1540496x.2015.1021605.

Kim, C.H. and Scullion, H. (2011), "Exploring the links between corporate social responsibility and global talent management: a comparative study of the UK and Korea”, European Journal of International Management, Vol. 5 No. 5, pp. 501-523.

Klooster, D. and Mercado-Celis, A. (2016), "Sustainable production networks: capturing value for labour and nature in a furniture production network in Oaxaca, Mexico", Regional Studies, Vol. 50 No. 11, pp. 1889-1902, doi: 10.1080/00343404.2015.1071915.

Knorringa, P. and Pegler, L. (2006), "Globalisation, firm upgrading and impacts on labour”, Tijdschrift Voor Economische En Sociale Geografie, Vol. 97 No. 5, pp. 470-479, doi: 10.1111/j.14679663.2006.00357.x.

Kobrin, S.J. (2009), "Private political authority and public responsibility: transnational politics, transnational firms, and human rights", Business Ethics Quarterly, Vol. 19 No. 3, pp. 349-374.

Koerber, C.P. (2009), "Corporate responsibility standards: current implications and future possibilities for peace through commerce", Journal of Business Ethics, Vol. 89 No. 4, pp. 461-480, doi: 10.1007/ s10551-010-0397-1. 
Kolk, A. and Lenfant, F. (2010), "Mnc reporting on csr and conflict in Central Africa", Journal of Business Ethics, Vol. 93 No. 2, pp. 241-255, doi: 10.1007/s10551-009-0271-1.

Kolk, A. and Lenfant, F. (2013), "Multinationals, csr and partnerships in Central African conflict countries", Corporate Social Responsibility and Environmental Management, Vol. 20 No. 1, pp. 43-54, doi: 10.1002/csr.1277.

Krueger, D.A. (2008), "The ethics of global supply chains in china - convergences of east and west", Journal of Business Ethics, Vol. 79 Nos 1/2, pp. 113-120, doi: 10.1007/s10551-007-9393-5.

Lakhani, T., Kuruvilla, S. and Avgar, A. (2013), "From the firm to the network: global value chains and employment relations theory", British Journal of Industrial Relations, Vol. 51 No. 3, pp. 440-472, doi: $10.1111 / b j i r .12015$.

Lambooy, T. (2011), "Corporate social responsibility: sustainable water use”, Journal of Cleaner Production, Vol. 19 No. 8, pp. 852-866, doi: 10.1016/j.jclepro.2010.09.009.

Lattemann, C., Fetscherin, M., Alon, I., Li, S.M. and Schneider, A.M. (2009), "Csr communication intensity in Chinese and Indian multinational companies", Corporate Governance: An International Review, Vol. 17 No. 4, pp. 426-442, doi: 10.1111/j.1467-8683.2009.00758.x.

Lauwo, S.G., Otusanya, O.J. and Bakre, O. (2016), "Corporate social responsibility reporting in the mining sector of Tanzania (lack of) government regulatory controls and ngo activism", Accounting, Auditing and Accountability Journal, Vol. 29 No. 6, pp. 1038-1074, doi: 10.1108/aaaj-06-2013-1380.

LeBaron, G. and Ruhmkorf, A. (2017), "Steering csr through home state regulation: a comparison of the impact of the UK bribery act and modern slavery act on global supply chain governance", Global Policy, Vol. 8, pp. 15-28, doi: 10.1111/1758-5899.12398.

Lee, J. and Gereffi, G. (2015), "Global value chains, rising power firms and economic and social upgrading”, Critical Perspectives on International Business, Vol. 11 No. 3/4, pp. 319, doi: 10.1108/ cpoib-03-2014-0018.

Lee, J., Gereffi, G. and Beauvais, J. (2012), "Global value chains and agrifood standards: challenges and possibilities for smallholders in developing countries", Proceedings of the National Academy of Sciences of the United States of America, Vol. 109 No. 31, pp. 12326-12331, doi: 10.1073/ pnas.0913714108.

Li, N. and Murphy, W.H. (2012), "A three-country study of unethical sales behaviors”, Journal of Business Ethics, Vol. 111 No. 2, pp. 219-235, doi: 10.1007/s10551-012-1203-z.

Lim, S.J. and Phillips, J. (2008), "Embedding csr values: the global footwear industry's evolving governance structure”, Journal of Business Ethics, Vol. 81 No. 1, pp. 143-156, doi: 10.1007/s10551-007-9485-2.

Lindgreen, A. (2004), "Corruption and unethical behavior: report on a set of danish guidelines", Journal of Business Ethics, Vol. 51 No. 1, pp. 31-39, doi: 10.1023/b:busi.0000032388.68389.60.

Linnenluecke, M.K., Smith, T. and McKnight, B. (2016), "Environmental finance: a research agenda for interdisciplinary finance research”, Economic Modelling, Vol. 59, pp. 124-130, doi: 10.1016/j. econmod.2016.07.010.

Ljung, A. and Pahlberg, C. (2015), "Subsidiary strategy processes in Latin America", European Business Review, Vol. 27 No. 5, pp. 535-550, doi: 10.1108/ebr-04-2013-0074.

Lober, D.J. (1997), "Explaining the formation of business-environmentalist collaborations: collaborative windows and the paper task force", Policy Sciences, Vol. 30 No. 1, pp. 1-24, doi: 10.1023/ a:1004201611394.

London, T. and Hart, S.L. (2004), "Reinventing strategies for emerging markets: beyond the transnational model”, Journal of International Business Studies, Vol. 35 No. 5, pp. 350-370, doi: 10.1057/palgrave.jibs.8400099.

Lopatta, K., Jaeschke, R., Tchikov, M. and Lodhia, S. (2017), "Corruption, corporate social responsibility and financial constraints: international firm-level evidence", European Management Review, Vol. 14 No. 1, pp. 47-65, doi: 10.1111/emre.12098. 
CPOIB 16,1

Lorenzo, O., Esqueda, P. and Larson, J. (2010), "Safety and ethics in the global workplace: asymmetries in culture and infrastructure", Journal of Business Ethics, Vol. 92 No. 1, pp. 87-106, doi: 10.1007/ s10551-009-0142-9.

Lozano, J.F. and Boni, A. (2002), "The impact of the multinational in the development: an ethical challenge", Journal of Business Ethics, Vol. 39 Nos 1/2, pp. 169-178, doi: 10.1023/ a:1016360823980.

Lucea, R. (2010), "How we see them versus how they see themselves a cognitive perspective of firm-ngo relationships", Business and Society, Vol. 49 No. 1, pp. 116-139, doi: 10.1177/0007650309345459.

Lund-Thomsen, P. and Nadvi, K. (2010), "Clusters, chains and compliance: corporate social responsibility and governance in football manufacturing in South asia", Journal of Business Ethics, Vol. 93 No. 2, pp. 201-222, doi: 10.1007/s10551-010-0561-7.

Luo, Y. (2017), "Development of the foreign trade economy of china under the new normal context of global trade", Agro Food Industry Hi-Tech, Vol. 28 No. 1, pp. 1651-1655.

Luo, Y.D. (2006), "Political behavior, social responsibility, and perceived corruption: a structuration perspective", Journal of International Business Studies, Vol. 37 No. 6, pp. 747-766, doi: 10.1057/ palgrave.jibs.8400224.

Luo, Y.D. (2011), "Strategic responses to perceived corruption in an emerging market: lessons from mnes investing in china", Business and Society, Vol. 50 No. 2, pp. 350-387, doi: 10.1177/ 0007650307313362.

Lustig, D. (2014), "Three paradigms of corporate responsibility in international law the kiobel moment", Journal of International Criminal Justice, Vol. 12 No. 3, pp. 593-614, doi: 10.1093/jicj/mqu040.

Lyons, M., Bartlett, J. and McDonald, P. (2016), "Corporate social responsibility in junior and mid-tier resources companies operating in developing nations - beyond the public relations offensive", Resources Policy, Vol. 50, pp. 204-213, doi: 10.1016/j.resourpol.2016.10.005.

McClintock, B. (1999), "The multinational corporation and social justice: experiments in supranational governance", Review of Social Economy, Vol. 57 No. 4, pp. 507-522, doi: 10.1080/ 00346769900000019 .

McQuilken, J.T. (2016), "Ethical gold' in Sub-Saharan Africa: a viable empowerment strategy?", International Development Planning Review, Vol. 38 No. 2, pp. 179-199, doi: 10.3828/ idpr.2016.9.

Ma, H.Y., Zeng, S.X., Shen, G.Q., Lin, H. and Chen, H.Q. (2016), "International diversification and corporate social responsibility an empirical study of chinese contractors", Management Decision, Vol. 54 No. 3, pp. 750-774, doi: 10.1108/md-07-2015-0322.

Maertens, M., Colen, L. and Swinnen, J.F.M. (2011), "Globalisation and poverty in Senegal: a worst case scenario?”, European Review of Agricultural Economics, Vol. 38 No. 1, pp. 31-54.doi: 10.1093/erae/ jbq053

Mahutga, M.C. (2012), "When do value chains go global? A theory of the spatialization of global value chains", Global Networks, Vol. 12 No. 1, pp. 1-21, doi: 10.1111/j.1471-0374.2011.00322.x.

Mak, A.K.Y., Chaidaroon, S. and Pang, A. (2015), "Mncs and csr engagement in asia: a dialectical model”, Asia Pacific Public Relations Journal, Vol. 16 No. 1, pp. 37-60.

Makela, H. and Nasi, S. (2010), "Social responsibilities of mncs in downsizing operations a finnish forest sector case analysed from the stakeholder, social contract and legitimacy theory point of view", Accounting Auditing and Accountability Journal, Vol. 23 No. 2, pp. 149-174, doi: 10.1108/ 09513571011023174.

Mamic, I. (2005), "Managing global supply chain: the sports footwear, apparel and retail sectors", Journal of Business Ethics, Vol. 59 Nos 1/2, pp. 81-100, doi: 10.1007/s10551-005-3415-y.

Mannion, A.M. (1995), "Biodiversity, biotechnology, and business", Environmental Conservation, Vol. 22 No. 3, pp. 201-229. 
Marano, V. and Kostova, T. (2016), "Unpacking the institutional complexity in adoption of csr practices in multinational enterprises", Journal of Management Studies, Vol. 53 No. 1, pp. 28-54, doi: $10.1111 /$ joms.12124.

Martin, J. (2013), "Business and human rights: what's the board got to do with it?", University of Illinois Law Review, Vol. 3, pp. 959-999.

Mijatovic, I.S. and Stokic, D. (2010), "The influence of internal and external codes on csr practice: the case of companies operating in Serbia", Journal of Business Ethics, Vol. 94 No. 4, pp. 533-552, doi: 10.1007/s10551-009-0280-0.

Social value creation of MNEs

Mingers, J. and Willmott, H. (2013), “Taylorizing business school research: on the 'one best way' performative effects of journal ranking lists”, Human Relations, Vol. 66 No. 8, pp. 1051-1073, doi: $10.1177 / 0018726712467048$.

Miska, C., Witt, M.A. and Stahl, G.K. (2016), "Drivers of global csr integration and local csr responsiveness: evidence from chinese mnes”, Business Ethics Quarterly, Vol. 26 No. 3, pp. 317-345, doi: 10.1017/beq.2016.13.

Mithani, M.A. (2017), "Liability of foreignness, natural disasters, and corporate philanthropy", Journal of International Business Studies, Vol. 48 No. 8, pp. 941-963, doi: 10.1057/s41267-017-0104-x.

Mollenkopf, D., Stolze, H., Tate, W.L. and Ueltschy, M. (2010), "Green, lean, and global supply chains”, International Journal of Physical Distribution and Logistics Management, Vol. 40 Nos 1/2, pp. 14-41, doi: 10.1108/09600031011018028.

Momin, M.A. and Parker, L.D. (2013), "Motivations for corporate social responsibility reporting by mnc subsidiaries in an emerging country: the case of Bangladesh", British Accounting Review, Vol. 45 No. 3, pp. 215-228, doi: 10.1016/j.bar.2013.06.007.

Monastra, G. and Rossi, L. (2003), "Transgenic foods as a tool for malnutrition elimination and their impact on agricultural systems", Rivista Di Biologia-Biology Forum, Vol. 96 No. 3, pp. 363-383.

Monfort, A. and Villagra, N. (2016), "Corporate social responsibility and corporate foundations in building responsible brands", El Profesional de la Información, Vol. 25 No. 5, pp. 767-777, doi: 10.3145/epi.2016.sep.07.

Morgenroth, A. and Luiz, J.M. (2017), "Corporate social responsibility mandates within German multinational enterprises in Sub-Saharan Africa", European Journal of International Management, No. 6, pp. 624-646, doi: 10.1504/ejim.2016.10000339.

Morsing, M. and Perrini, F. (2009), "Csr in smes: Do smes matter for the csr agenda?", Business Ethics: A European Review, Vol. 18 No. 1, pp. 1-6, doi: 10.1111/j.1467-8608.2009.01544.x.

Mosley, L. (2017), "Workers' rights in global value chains: possibilities for protection and for peril", New Political Economy, Vol. 22 No. 2, pp. 153-168, doi: 10.1080/13563467.2016.1273339.

Muller, A. and Kolk, A. (2015), "Responsible tax as corporate social responsibility: the case of multinational enterprises and effective tax in India”, Business and Society, Vol. 54 No. 4, pp. 435-463, doi: 10.1177/0007650312449989.

Murphy, S.D. (2005), "Taking multinational corporate codes of conduct to the next level”, Columbia Journal of Transnational Law, Vol. 43 No. 2, pp. 389-433.

Myer, A.T., Thoroughgood, C.N. and Mohammed, S. (2016), "Complementary or competing climates? Examining the interactive effect of service and ethical climates on company-level financial performance", Journal of Applied Psychology, Vol. 101 No. 8, pp. 1178-1190, doi: 10.1037/apl0000119.

Mzembe, A.N. and Meaton, J. (2014), "Driving corporate social responsibility in the Malawian mining industry: a stakeholder perspective", Corporate Social Responsibility and Environmental Management, Vol. 21 No. 4, pp. 189-201.doi: 10.1002/csr.1319

Neglia, M. (2016), "The ungps - five years on from consensus to divergence in public regulation on business and human rights", Netherlands Quarterly of Human Rights, Vol. 34 No. 4, pp. 289-317.

Niewiadomski, P. (2015), "International hotel groups and regional development in Central and Eastern europe", Tourism Geographies, Vol. 17 No. 2, pp. 173-191, doi: 10.1080/14616688.2014.997278. 


\section{CPOIB} 16,1

Noor, F.M.M., Gassner, A., Terheggen, A. and Dobie, P. (2017), "Beyond sustainability criteria and principles in palm oil production: addressing consumer concerns through insetting", Ecology and Society, Vol. 22 No. 2, doi:, doi: 10.5751/es-09172-220205.

Nygaard, A., Biong, H., Silkoset, R. and Kidwell, R.E. (2017), "Leading by example: values-based strategy to instill ethical conduct", Journal of Business Ethics, Vol. 145 No. 1, pp. 133-139, doi: 10.1007/s10551-015-2885-9.

Nyuur, R.B., Ofori, D.F. and Debrah, Y.A. (2016), “The impact of fdi inflow on domestic firms' uptake of csr activities: the moderating effects of host institutions", Thunderbird International Business Review, Vol. 58 No. 2, pp. 147-159, doi: 10.1002/tie.21744.

Oetzel, J. and Doh, J.P. (2009), "Mnes and development: a review and reconceptualization", Journal of World Business, Vol. 44 No. 2, pp. 108-120, doi: 10.1016/j.jwb.2008.05.001.

Oetzel, J. and Getz, K. (2012), "Why and how might firms respond strategically to violent conflict?", Journal of International Business Studies, Vol. 43 No. 2, pp. 166-186, doi: 10.1057/jibs.2011.50.

Palmer, E. (2001), "Multinational corporations and the social contract", Journal of Business Ethics, Vol. 31 No. 3, pp. 245-258, doi: 10.1023/a:1010737903028.

Pangsapa, P. and Smith, M.J. (2008), "Political economy of southeast Asian borderlands: migration, environment, and developing country firms", Journal of Contemporary Asia, Vol. 38 No. 4, pp. 485-514, doi: 10.1080/00472330802309369.

Parella, K. (2014), "Outsourcing corporate accountability”, Washington Law Review, Vol. 89 No. 3, pp. $747-818$.

Park, B.I. and Choi, J. (2015), "Stakeholder influence on local corporate social responsibility activities of Korean multinational enterprise subsidiaries", Emerging Markets Finance and Trade, Vol. 51 No. 2, pp. 335-350, doi: 10.1080/1540496x.2015.1021609.

Pedersen, E.R.G. and Gwozdz, W. (2014), "From resistance to opportunity-seeking: strategic responses to institutional pressures for corporate social responsibility in the Nordic fashion industry", Journal of Business Ethics, Vol. 119 No. 2, pp. 245-264, doi: 10.1007/s10551-013-1630-5.

Pedersen, E.R. and Neergaard, P. (2009), "What matters to managers? The whats, whys, and hows of corporate social responsibility in a multinational corporation", Management Decision, Vol. 47 No. 8, pp. 1261-1280, doi: 10.1108/00251740910984532.

Pedrini, M., Bramanti, V. and Cannatelli, B. (2016), "The impact of national culture and social capital on corporate social responsibility attitude among immigrants entrepreneurs", Journal of Management and Governance, Vol. 20 No. 4, pp. 759-787, doi: 10.1007/s10997-015-9327-z.

Perez-Aleman, P. and Sandilands, M. (2008), "Building value at the top and the bottom of the global supply chain: Mnc-ngo partnerships”, California Management Review, Vol. 51 No. 1, pp. 24-49.

Perrot, F. (2017), "Multinational corporations' strategies at the base of the pyramid: an action research inquiry”, Journal of Business Ethics, Vol. 146 No. 1, pp. 59-76, doi: 10.1007/s10551-015-2785-z.

Pickren, G. (2014), "Political ecologies of electronic waste: uncertainty and legitimacy in the governance of e-waste geographies", Environment and Planning A: Economy and Space, Vol. 46 No. 1, pp. 26-45, doi: $10.1068 / \mathrm{a} 45728$.

Pinkse, J. and Kolk, A. (2012), "Multinational enterprises and climate change: exploring institutional failures and embeddedness", Journal of International Business Studies, Vol. 43 No. 3, pp. 332-341, doi: 10.1057/jibs.2011.56.

Pinkse, J., Kuss, M.J. and Hoffmann, V.H. (2010), "On the implementation of a 'global' environmental strategy: the role of absorptive capacity”, International Business Review, Vol. 19 No. 2, pp. 160-177, doi: 10.1016/j.ibusrev.2009.11.005.

Pipkin, S. (2011), "Local means in value chain ends: dynamics of product and social upgrading in apparel manufacturing in Guatemala and Colombia", World Development, Vol. 39 No. 12, pp. 2119-2131, doi: 10.1016/j.worlddev.2011.04.016. 
Plank, L. and Staritz, C. (2016), "Social up- and downgrading of apparel workers in Romania: fast fashion, post-socialist transformation, Europeanization, and the global economic crisis", Transfer-European Review of Labour and Research, Vol. 22 No. 2, pp. 233-248, doi: 10.1177/ 1024258916636577.

Powell, D. and Gard, M. (2015), "The governmentality of childhood obesity: Coca-Cola, public health and primary schools", Discourse-Studies in the Cultural Politics of Education, Vol. 36 No. 6, pp. 854-867, doi: 10.1080/01596306.2014.905045.

Pupovac, S. and Moerman, L. (2017), "Hybrid accounts: shell's letter to mr and mrs shareholder", Accounting, Auditing and Accountability Journal, Vol. 30 No. 5, pp. 1184-1201, doi: 10.1108/aaaj-05-2015-2068.

Raj-Reichert, G. (2013), "Safeguarding labour in distant factories: health and safety governance in an electronics global production network", Geoforum, Vol. 44, pp. 23-31, doi: 10.1016/j. geoforum.2012.05.007.

Ramamurti, R. (2004), "Developing countries and mnes: extending and enriching the research agenda", Journal of International Business Studies, Vol. 35 No. 4, pp. 277-283, doi: 10.1057/palgrave.jibs.8400087.

Reed, D. (2009), "What do corporations have to do with fair trade? Positive and normative analysis from a value chain perspective”, Journal of Business Ethics, Vol. 86 No. 1, pp. 3-26, doi: 10.1007/s10551008-9757-5.

Regan, M.C. (2016), "Lawyers, globalization, and transnational governance regimes", Annual Review of Law and Social Science, Vol. 12 No. 1, pp. 133-152, doi: 10.1146/annurev-lawsocsci-110413-030617.

Reimann, F., Ehrgott, M., Kaufmann, L. and Carter, C.R. (2012), "Local stakeholders and local legitimacy: MNEs social strategies in emerging economies", Journal of International Management, Vol. 18 No. 1, pp. 1-17, doi: 10.1016/j.intman.2011.06.002.

Riaz, Z., Ray, S., Ray, P.K. and Kumar, V. (2015), "Disclosure practices of foreign and domestic firms in australia”, Journal of World Business, Vol. 50 No. 4, pp. 781-792, doi: 10.1016/j.jwb.2015.04.001.

Riikkinen, R., Kauppi, K. and Salmi, A. (2017), "Learning sustainability? Absorptive capacities as drivers of sustainability in mncs' purchasing”, International Business Review, Vol. 26 No. 6, pp. 1075-1087, doi: 10.1016/j.ibusrev.2017.04.001.

Rim, H. and Song, D. (2017), "Corporate message strategies for global csr campaigns the mediating role of perceived altruism", Corporate Communications: An International Journal, Vol. 22 No. 3, pp. 383-400, doi: 10.1108/ccij-01-2017-0007.

Ritvala, T., Salmi, A. and Andersson, P. (2014), "Mncs and local cross-sector partnerships: the case of a smarter Baltic sea”, International Business Review, Vol. 23 No. 5, pp. 942-951, doi: 10.1016/j.ibusrev.2014.02.006.

Rockstrom, J., Steffen, W., Noone, K., Persson, A., Chapin, F.S., Lambin, E. and Foley, J. (2009a), "Planetary boundaries: exploring the safe operating space for humanity", Ecology and Society, Vol. 14 No. 2, pp. 33.

Rockstrom, J., Steffen, W., Noone, K., Persson, A., Chapin, F.S., Lambin, E.F. and Foley, J.A. (2009b), “A safe operating space for humanity”, Nature, Vol. 461 No. 7263, pp. 472-475, doi: 10.1038/461472a.

Rothe, D.L. (2010), "Facilitating corruption and human rights violations: the role of international financial institutions", Crime, Law and Social Change, Vol. 53 No. 5, pp. 457-476, doi: 10.1007/ s10611-010-9236-7.

Rueda, X., Garrett, R.D. and Lambin, E.F. (2017), "Corporate investments in supply chain sustainability: selecting instruments in the Agri-food industry", Journal of Cleaner Production, Vol. 142, pp. 2480-2492, doi: 10.1016/j.jclepro.2016.11.026.

Rygh, A. (2019), "Social value creation by multinational enterprises: the next 'big question", for international business research? Critical Perspectives on International Business.

Salcito, K., Singer, B.H., Weiss, M.G., Winkler, M.S., Krieger, G.R., Wielga, M. and Utzinger, J. (2014), "Multinational corporations and infectious disease: embracing human rights management techniques”, Infectious Diseases of Poverty, Vol. 3 No. 1, doi:, doi: 10.1186/2049-9957-3-39. 
CPOIB 16,1

Salcito, K., Utzinger, J., Krieger, G.R., Wielga, M., Singer, B.H., Winkler, M.S. and Weiss, M.G. (2015), "Experience and lessons from health impact assessment for human rights impact assessment", Bmc International Health and Human Rights, Vol. 15 No. 1, doi:, doi: 10.1186/s12914-015-0062-y.

Sampson, H. and Ellis, N. (2015), "Elusive corporate social responsibility (csr) in global shipping", Journal of Global Responsibility, Vol. 6 No. 1, pp. 80-98, doi: 10.1108/jgr-08-2014-0028.

Samy, M., Ogiri, H.I. and Bampton, R. (2015), "Examining the public policy perspective of csr implementation in Sub-Saharan Africa", Social Responsibility Journal, Vol. 11 No. 3, pp. 553-572, doi: 10.1108/srj-02-2013-0009.

Sarfaty, G.A. (2015), "Shining light on global supply chains", Harvard International Law Journal, Vol. 56 No. 2, pp. 419-463.

Sargent, J. and Matthews, L. (1999), "Exploitation or choice? Exploring the relative attractiveness of employment in the maquiladoras", Journal of Business Ethics, Vol. 18 No. 2, pp. 213-227, doi: 10.1023/a:1005742629319.

Scheinin, M. (2012), "International organizations and transnational corporations at a world court of human rights", Global Policy, Vol. 3 No. 4, pp. 488-491, doi: 10.1111/j.1758-5899.2012.00204.x.

Schembera, S. and Scherer, A.G. (2017), "Organizational strategies in the context of legitimacy loss: radical versus gradual responses to disclosed corruption”, Strategic Organization, Vol. 15 No. 3, pp. 301-337, doi: 10.1177/1476127016685237.

Scherer, A.G., Palazzo, G. and Baumann, D. (2006), "Global rules and private actors: toward a new role of the transnational corporation in global governance", Business Ethics Quarterly, Vol. 16 No. 4, pp. 505-532.

Schrader, C., Freimann, J. and Seuring, S. (2012), "Business strategy at the base of the pyramid", Business Strategy and the Environment, Vol. 21 No. 5, pp. 281-298, doi: 10.1002/bse.727.

Seck, S.L. (2016), "Indigenous rights, environmental rights, or stakeholder engagement? Comparing ifc and OECD approaches to implementation of the business responsibility to respect human rights", Mcgill International Journal of Sustainable Development Law and Policy, Vol. 12 No. 1, pp. 47-91.

Seidman, G. (2005), "Stateless' regulation and consumer pressure: historical experiences of transnational corporate monitoring", New Directions in the Sociology of Global Development, Vol. 11, pp. 175-207, doi: 10.1016/s1057-1922(05)11007-5.

Selmier, W.T., Newenham-Kahindi, A. and Oh, C.H. (2015), "Understanding the words of relationships": language as an essential tool to manage csr in communities of place", Journal of International Business Studies, Vol. 46 No. 2, pp. 153-179, doi: 10.1057/jibs.2014.58.

Sesan, T., Raman, S., Clifford, M. and Forbes, I. (2013), "Corporate-led sustainable development and energy poverty alleviation at the bottom of the pyramid: the case of the cleancook in Nigeria", World Development, Vol. 45, pp. 137-146, doi: 10.1016/j.worlddev.2012.10.009.

Sethi, S.P. and Rovenpor, J.L. (2016), "The role of ngos in ameliorating sweatshop-like conditions in the global supply chain: the case of fair labor association (fla), and social accountability international (sai)", Business and Society Review, Vol. 121 No. 1, pp. 5-36, doi: 10.1111/basr.12079.

Shah, K.U. and Arjoon, S. (2015), "Through thick and thin? How self-determination drives the corporate sustainability initiatives of multinational subsidiaries", Business Strategy and the Environment, Vol. 24 No. 6, pp. 565-582, doi: 10.1002/bse.1838.

Shen, J. (2011), "Developing the concept of socially responsible international human resource management", International Journal of Human Resource Management, Vol. 22 No. 6, pp. 1351-1363, doi: 10.1080/09585192.2011.559104.

Simons, P. (2004), "Corporate voluntarism and human rights - the adequacy and effectiveness of voluntary self-regulation regimes", Relations Industrielles-Industrial Relations, Vol. 59 No. 1, pp. 101-141.

Singh, J.A., Daar, A.S. and Singer, P.A. (2010), "Shared principles of ethics for infant and young child nutrition in the developing world", Bmc Public Health, Vol. 10 No. 1, doi:, doi: 10.1186/1471-2458-10-321. 
Sinkovics, N., Hoque, S.F. and Sinkovics, R.R. (2016), "Rana plaza collapse aftermath: are csr compliance and auditing pressures effective?", Accounting, Auditing and Accountability Journal, Vol. 29 No. 4, pp. 617-649, doi: 10.1108/AAAJ-07-2015-2141.

Sinkovics, N., Sinkovics, R.R. and Archie-Acheampong, J. (2019), "An overview of social responsibility dimensions in international business”, in Leonidou, L.C. Katsikeas, C.S., Samiee S. and Leonidou C.N. (Eds), Sociallyresponsible International Business: Critical Issues and the Way Forward.

Sinkovics, N., Sinkovics, R.R., Hoque, S.F. and Czaban, L. (2015), "A reconceptualisation of social value creation as social constraint alleviation", Critical Perspectives on International Business, Vol. 11 Nos 3/4, pp. 340-363, doi: 10.1108/cpoib-06-2014-0036.

Sinkovics, N., Sinkovics, R.R. and Yamin, M. (2014), "The role of social value creation in business model formulation at the bottom of the pyramid - implications for mnes?", International Business Review, Vol. 23 No. 4, pp. 692-707, doi: 10.1016/j.ibusrev.2013.12.004.

Skippari, M. and Pajunen, K. (2010), "Mne-ngo-host government relationships in the escalation of an fdi conflict", Business and Society, Vol. 49 No. 4, pp. 619-651, doi: 10.1177/0007650310377312.

Sluyterman, K. (2012), "Corporate social responsibility of Dutch entrepreneurs in the twentieth century", Enterprise and Society, Vol. 13 No. 2, pp. 313-349, doi: 10.1093/es/khs001.

Smith, D.N. (2010), "The way we think: Ethics, health and the environment in international business", Asian Journal of Wto and International Health Law and Policy, Vol. 5 No. 1, pp. 25-52.

Smith, S. and Barrientos, S. (2005), "Fair trade and ethical trade: are there moves towards convergence?”, Sustainable Development, Vol. 13 No. 3, pp. 190-198, doi: 10.1002/sd.277.

Sobczak, A. (2007), "Legal dimensions of international framework agreements in the field of corporate social responsibility", Relations Industrielles-Industrial Relations, Vol. 62 No. 3, pp. 466-491.

Soundararajan, V. and Brown, J.A. (2016), "Voluntary governance mechanisms in global supply chains: beyond csr to a stakeholder utility perspective", Journal of Business Ethics, Vol. 134 No. 1, pp. 83-102, doi: 10.1007/s10551-014-2418-y.

Srikantia, J. (2016), "The structural violence of globalization", Critical Perspectives on International Business, Vol. 12 No. 3, pp. 222-258, doi: 10.1108/cpoib-09-2015-0040.

Sroufe, R. (2017), "Integration and organizational change towards sustainability", Journal of Cleaner Production, Vol. 162, pp. 315-329, doi: 10.1016/j.jclepro.2017.05.180.

Steffen, W., Richardson, K., Rockstrom, J., Cornell, S.E., Fetzer, I., Bennett, E.M., Biggs, R., Carpenter, S.R., Vries, W.D., de Wit, C.A., Folke, C., Gerten, D., Heinke, J., Mace, G.M., Persson, L.M., Ramanathan, V., Reyers, B. and Sorlin, S. (2015), "Planetary boundaries: guiding human development on a changing planet”, Science, Vol. 347 No. 6223, pp. 11, doi: 10.1126/science.1259855.

Stringer, C., Simmons, G., Coulston, D. and Whittaker, D.H. (2014), "Not in New Zealand's waters, surely? Linking labour issues to gpns”, Journal of Economic Geography, Vol. 14 No. 4, pp. 739-758, doi: 10.1093/jeg/lbt027.

Surroca, J., Tribo, J.A. and Zahra, S.A. (2013), "Stakeholder pressure on mnes and the transfer of socially irresponsible practices to subsidiaries", Academy of Management Journal, Vol. 56 No. 2 , pp. 549-572, doi: 10.5465/amj.2010.0962.

Swoboda, B., Huber, C., Schuster, T. and Hirschmann, J. (2017), "Corporate reputation effects across nations: the impact of country distances and firm-specific resources", Management International Review, Vol. 57 No. 5, pp. 717-748, doi: 10.1007/s11575-017-0313-3.

Tait, J. and Chataway, J. (2007), "The governance of corporations, technological change, and risk: examining industrial perspectives on the development of genetically modified crops", Environment and Planning C: Government and Policy, Vol. 25 No. 1, pp. 21-37, doi: 10.1068/c0615j.

Tan, J. (2009), "Institutional structure and firm social performance in transitional economies: evidence of multinational corporations in china", Journal of Business Ethics, Vol. 86 No. 2, pp. 171-189, doi: 10.1007/s10551-009-0193-y. 


\section{CPOIB} 16,1

Tarnovskaya, V. and Biedenbach, G. (2016), "Multiple stakeholders and b2b branding in emerging markets", Qualitative Market Research: An International Journal, Vol. 19 No. 3, pp. 287-309, doi: 10.1108/qmr-06-2015-0051.

Tatoglu, E., Bayraktar, E., Sahadev, S., Demirbag, M. and Glaister, K.W. (2014), "Determinants of voluntary environmental management practices by mne subsidiaries", Journal of World Business, Vol. 49 No. 4, pp. 536-548, doi: 10.1016/j.jwb.2013.12.007.

Tausch, A. and Heshmati, A. (2012), "The effects of multinational corporation (mnc) penetration on the global political economy. A re-analysis of a recurrent sociological proposition with contemporary data", Sociologia, Vol. 44 No. 3, pp. 314-347.

Taylor, P., D'Cruz, P., Noronha, E. and Scholarios, D. (2014), "From boom to where? The impact of crisis on work and employment in Indian bpo", New Technology Work and Employment, Vol. 29 No. 2, pp. 105-123, doi: 10.1111/ntwe.12027.

Taylor, M. Nelsen, A. and Brooks, L. (2019), "Youth climate strikes to take place in more than 100 countries", The Guardian.(accsseced 14 March 2019)

Tolentino-Zondervan, F., Berentsen, P., Bush, S., Idemne, J., Babaran, R. and Lansink, A.O. (2016), "Comparison of private incentive mechanisms for improving sustainability of Filipino tuna fisheries”, World Development, Vol. 83, pp. 264-279, doi: 10.1016/j.worlddev.2016.01.011.

Tong, X. and Wang, J.C. (2004), "Transnational flows of e-waste and spatial patterns of recycling in china", Eurasian Geography and Economics, Vol. 45 No. 8, pp. 608-621, doi: 10.2747/1538-7216.45.8.608.

Touboulic, A., Chicksand, D. and Walker, H. (2014), "Managing imbalanced supply chain relationships for sustainability: a power perspective", Decision Sciences, Vol. 45 No. 4, pp. 577-619, doi: 10.1111/deci.12087.

Tsai, P.C.F. and Shih, C.T. (2013), "Labor union negotiations: stepping stones or stumbling blocks for a responsible downsizing strategy? Empirical tests in Taiwan", International Journal of Human Resource Management, Vol. 24 No. 3, pp. 601-620, doi: 10.1080/09585192.2012.694112.

Tuokuu, F.X.D. and Amponsah-Tawiah, K. (2016), "Corporate social responsibility: is it an alternative to government?”, Journal of Global Responsibility, Vol. 7 No. 1, pp. 26-38, doi: 10.1108/jgr-05-2015-0007.

Turner, F.C. and Corbacho, A.L. (2000), "New roles for the state", International Social Science Journal, Vol. 52 No. 163, pp. 109-120, doi: 10.1111/1468-2451.00242.

Tüselmann, H., Sinkovics, R.R. and Pishchulov, G. (2016), "Revisiting the standing of international business journals in the competitive landscape", Journal of World Business, Vol. 51 No. 4, pp. 487-498.available at: https://doi.org/10.1016/j.jwb.2016.01.006

Urban, B. and Hwindingwi, R. (2016), "The influence of institutional factors on mnc's triple bottom-line reporting a focus on African emerging markets (aems)", International Journal of Emerging Markets, Vol. 11 No. 4, pp. 497-513, doi: 10.1108/IJoEM-08-2015-0164.

Vellema, S. and van Wijk, J. (2015), "Partnerships intervening in global food chains: the emergence of co-creation in standard-setting and certification", Journal of Cleaner Production, Vol. 107, pp. 105-113, doi: 10.1016/j.jclepro.2014.03.090.

Venter, E.R., Stiglingh, M. and Smit, A.R. (2017), "Integrated thinking and the transparency of tax disclosures in the corporate reports of firms", Journal of International Financial Management and Accounting, Vol. 28 No. 3, pp. 394-427, doi: 10.1111/jifm.12064.

Verhezen, P. (2010), "Giving voice in a culture of silence. From a culture of compliance to a culture of integrity”, Journal of Business Ethics, Vol. 96 No. 2, pp. 187-206, doi: 10.1007/s10551-010-0458-5.

Vos, J. and Hinojosa, L. (2016), "Virtual water trade and the contestation of hydrosocial territories", Water International, Vol. 41 No. 1, pp. 37-53, doi: 10.1080/02508060.2016.1107682.

Wahl, A. and Bull, G.Q. (2014), "Mapping research topics and theories in private regulation for sustainability in global value chains", Journal of Business Ethics, Vol. 124 No. 4, pp. 585-608, doi: 10.1007/s10551-013-1889-6. 
Wang, H.Z. (2005), "Asian transnational corporations and labor rights: Vietnamese trade unions in Taiwan-invested companies", Journal of Business Ethics, Vol. 56 No. 1, pp. 43-53, doi: 10.1007/ s10551-004-1034-7.

Wang, H.M.D. and Sengupta, S. (2016), "Stakeholder relationships, brand equity, firm performance: a resource-based perspective", Journal of Business Research, Vol. 69 No. 12, pp. 5561-5568, doi: 10.1016/j.jbusres.2016.05.009.

Wehling, C., Hernandez, A.G., Osland, J., Osland, A., Deller, J., Tanure, B. and Sairaj, A. (2009), “An exploratory study of the role of hrm and the transfer of German mnc sustainability values to brazil”, European J. Of International Management, Vol. 3 No. 2, pp. 176-198.

Werner, M. (2016), "Global production networks and uneven development: exploring geographies of devaluation, disinvestment, and exclusion”, Geography Compass, Vol. 10 No. 11, pp. 457-469, doi: 10.1111/gec3.12295.

Werner, M., Bair, J. and Fernandez, V.R. (2014), "Linking up to development? Global value chains and the making of a post-Washington consensus", Development and Change, Vol. 45 No. 6, pp. 1219-1247, doi: 10.1111/dech.12132.

Wettstein, F. (2010), "The duty to protect: Corporate complicity, political responsibility, and human rights advocacy", Journal of Business Ethics, Vol. 96 No. 1, pp. 33-47, doi: 10.1007/s10551-010-0447-8.

Wettstein, F. (2012), "Csr and the debate on business and human rights: bridging the great divide", Business Ethics Quarterly, Vol. 22 No. 4, pp. 739-770.

Wichmann, B.K., Carter, C.R., Kaufmann, L. and Wilson, J.R. (2016), "Making environmental scm initiatives workmoving beyond the dyad to gain affective commitment", Journal of Supply Chain Management, Vol. 52 No. 1, pp. 21-40, doi: 10.1111/jscm.12095.

Wilde-Ramsing, J. (2017), "Quality kilowatts: a normative-empirical framework for assessing tnc performance on sustainable electricity provision in developing countries", Progress in Development Studies, Vol. 17 No. 2, pp. 131-147, doi: 10.1177/1464993416688827.

Williams, O.F. (2004), "The un global compact: the challenge and the promise", Business Ethics Quarterly, Vol. 14 No. 4, pp. 755-774.

Williams, G. and Zinkin, J. (2008), “The effect of culture on consumers' willingness to punish irresponsible corporate behaviour: applying hofstede's typology to the punishment aspect of corporate social responsibility", Business Ethics: A European Review, Vol. 17 No. 2, pp. 210-226, doi: 10.1111/j.1467-8608.2008.00532.x.

Willmott, H. (1995), "Managing the academics: commodification and control in the development of university education in the UK", Human Relations, Vol. 48 No. 9, pp. 993-1027, doi: 10.1177/ 001872679504800902.

Willmott, H. (2011), "Journal list fetishism and the perversion of scholarship: reactivity and the abs list", Organization, Vol. 18 No. 4, pp. 429-442, doi: 10.1177/1350508411403532.

Windsor, D. (2006), "Corporate social responsibility: three key approaches", Journal of Management Studies, Vol. 43 No. 1, pp. 93-114, doi: 10.1111/j.1467-6486.2006.00584.x.

Wu, J. (2001), "Pursuing international environmental tort claims under the atca: Beanal v", FreeportMcmoran. Ecology Law Quarterly, Vol. 28 No. 2, pp. 487-508.

Yang, J.S., McDaniel, P.A. and Malone, R.E. (2012), "A question of balance': addressing the public health impacts of multinational enterprises in the OECD guidelines for multinational enterprises", Global Public Health, Vol. 7 No. 10, pp. 1045-1061, doi: 10.1080/17441692.2012.729152.

Yeung, H.W.C. (2009), "Regional development and the competitive dynamics of global production networks: an east Asian perspective", Regional Studies, Vol. 43 No. 3, pp. 325-351, doi: 10.1080/ 00343400902777059 .

Yin, J.L., Feng, J.Y. and Wang, Y.Y. (2015), "Social media and multinational corporations' corporate social responsibility in china: the case of conocophillips oil spill incident", Ieee Transactions on Professional Communication, Vol. 58 No. 2, pp. 135-153, doi: 10.1109/tpc.2015.2433071. 
CPOIB 16,1

Yin, J.L. and Jamali, D. (2016), "Strategic corporate social responsibility of multinational companies subsidiaries in emerging markets: evidence from china”, Long Range Planning, Vol. 49 No. 5, pp. 541-558, doi: 10.1016/j.lrp.2015.12.024.

Ylonen, M. and Laine, M. (2015), "For logistical reasons only? A case study of tax planning and corporate social responsibility reporting", Critical Perspectives on Accounting, Vol. 33, pp. 5-23, doi: 10.1016/j.cpa.2014.12.001.

Yu, X.M. (2008), “Impacts of corporate code of conduct on labor standards: a case study of reebok's athletic footwear supplier factory in china", Journal of Business Ethics, Vol. 81 No. 3, pp. 513-529, doi: 10.1007/s10551-007-9521-2.

Zeriti, A., Robson, M.J., Spyropoulou, S. and Leonidou, C.N. (2014), "Sustainable export marketing strategy fit and performance", Journal of International Marketing, Vol. 22 No. 4, pp. 44-66.

Zhao, M., Tan, J. and Park, S.H. (2014), "From voids to sophistication: institutional environment and mnc csr crisis in emerging markets", Journal of Business Ethics, Vol. 122 No. 4, pp. 655-674, doi: 10.1007/s10551-013-1751-x.

\section{About the authors}

Noemi Sinkovics (PhD, Manchester) is a Lecturer in International Business and Management at Alliance Manchester Business School, UK, and currently Visiting Scholar at Temple University, Fox School of Business, Philadelphia, PA, USA. Her research focuses on international entrepreneurship, supplier capability development and upgrading in emerging markets and issues related to the business society interface including social value creation, business ethics and responsible innovation. She has published in journals such as International Business Review, International Marketing Review, Journal of Business Research, Critical Perspectives on International Business, Journal of International Management and European Journal of International Management. Noemi Sinkovics is the corresponding author and can be contacted at: noemi.sinkovics@manchester.ac.uk

Jason Archie-acheampong is a Postgraduate Research Student at Alliance Manchester Business School, UK. He obtained a master's degree in entrepreneurship and works on issues related to SMEs' responsible behavior.

For instructions on how to order reprints of this article, please visit our website: www.emeraldgrouppublishing.com/licensing/reprints.htm Or contact us for further details: permissions@emeraldinsight.com 